\title{
Age and paleomagnetism of the Okhotsk-Chukotka Volcanic Belt (OCVB) near Lake El'gygytgyn, Chukotka, Russia
}

\author{
D. B. Stone ${ }^{1}$, P. W. Layer ${ }^{1}$, and M. I. Raikevich ${ }^{2}$ \\ ${ }^{1}$ Geophysical Institute, University of Alaska, Fairbanks, Alaska, 99775, USA \\ ${ }^{2}$ Northeast Interdisciplinary Research Institute, 16 Portavaya St., Magadan, 685010, Russia
}

Abstract. Paleomagnetic results from the upper two thirds of the whole section of the Okhotsk-Chukotka Volcanic Belt (OCVB) volcanics exposed in the area around Lake El'gygytgyn, Chukotka yield stable, consistent magnetic vectors and well-preserved reversed directions. The magnetostratigraphy and ${ }^{40} \mathrm{Ar} /{ }^{39} \mathrm{Ar}$ geochronologic data reported here indicate that the sampled OCVB volcanics were erupted between about 90 and $67 \mathrm{Ma}$, and show no significant change in the apparent pole position over that time. The OCVB extends from northeast China, across Northeast Russia to the Bering Straight. This belt is made up of both extrusive and intrusive rocks, with the extrusive rocks and their associated sediments being dominant. The whole belt important in interpreting the paleogeography of the region because it overlies many of the accreted terranes of Northeast Russia. Most importantly, it overlies parts of the Chukotka-Alaska block which is thought to have moved out of the Arctic Ocean region, as well as terranes accreted from the south. These latter terranes have been rafted northwards on the paleo-plates of the Pacific, implying that the present relative paleogeography of all of the terranes overlain by the OCVB were essentially in place by $67 \mathrm{Ma}$, and possibly as early as $90 \mathrm{Ma}$. However, comparing our paleomagnetic pole position for the OCVB with those for North America and Eurasia (a proxy for Siberia) shows a statistically significant displacement of the OCVB pole to the south west. This implies that not only the OCVB, but the underlying terranes of northeast Russia, experienced southerly displacement with respect to the Siberian and North American platforms since the Late Cretaceous.

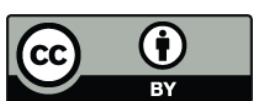

Correspondence to: D. B. Stone (dstone@gi.alaska.edu)

\section{Introduction}

The Okhotsk-Chukotka Volcanic Belt (OCVB) was formed in Late Cretaceous time, apparently as the result of subduction along an Andean type convergent continental margin, and this was followed followed by extension (Newberry et al., 1998). The extent of this Okhotsk-Chukotka belt per se is from the Chukotka Peninsula, adjacent to Alaska, through to northern China, a distance of about $3000 \mathrm{~km}$ (Fig. 1). Extrusive and intrusive rocks of the same age and general characteristics also extend across interior Alaska down as far as southern British Columbia.

Part of the importance of this belt stems from the fact that it overlaps many of the terranes that had already accreted to the Siberian platform. These include the Chukotka-Alaska terrane, which consists of Arctic Alaska (the Brooks Range and the Arctic Slope) and those parts of Chukotka north of the South Anuyi suture (Parfenov, 1991; Nokleberg et al., 1996) as well as parts of many of the terranes forming the Kolyma-Omolon Superterrane (Fig. 1). The ChukotkaArctic Alaska terranes had their origins in the Arctic ocean region, whereas the other terranes have been transported northwards on the plates of the Pacific. This implies that all of these terranes were in place with respect to each other by the time that the OCVB belt developed. Therefore the belt indicates that this part of the Arctic/Pacific margin was essentially in its present geographic form by the time that OCVB volcanism was initiated, but the terranes were not necessarily in their present positions with respect to the North American and Siberian platforms.

The age of the OCVB has been poorly understood, but now through a combination of recent geochronologic and paleontologic studies (Akinin and Khanchuk, 2005; Bely and Belaya, 1998; Hourigan and Akinin, 2004; Kelley et al., 1999) and the paleomagnetic data presented here it appears that the age span ranges from about Coniacian (88.5 Ma) to Maastrichtian (65 Ma) time. This study reports data on the paleomagnetism and the radiometric ages of a series of outcrops

Published by Copernicus Publications on behalf of the European Geosciences Union. 


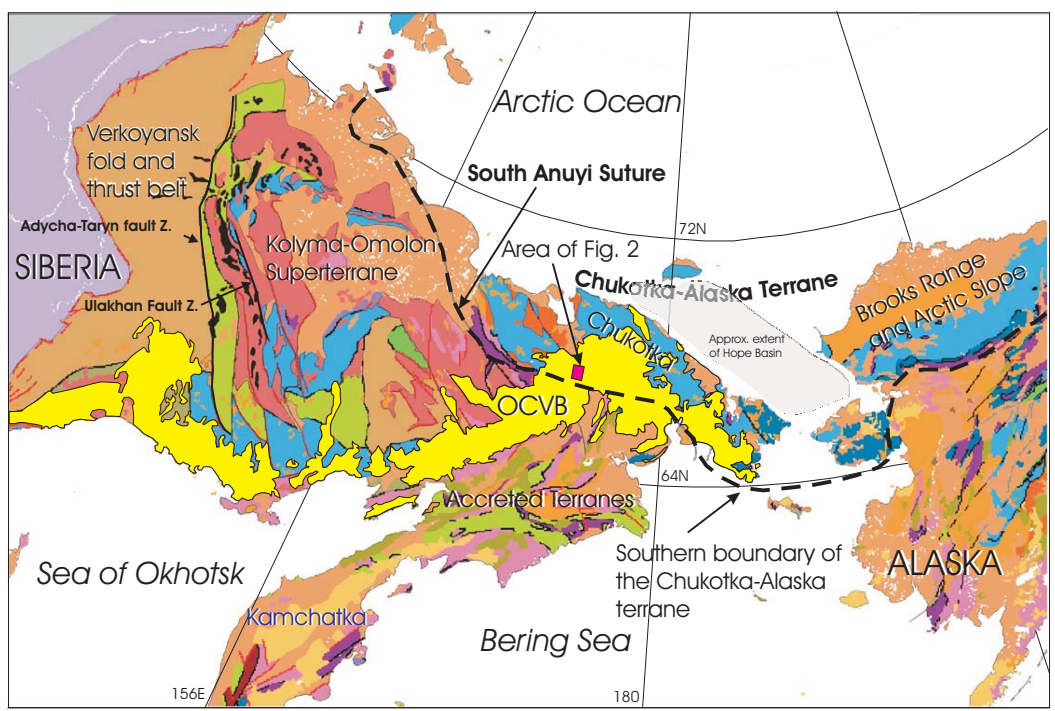

Fig. 1. Location map of the Okhotsk-Chukotka Volcanic Belt (OCVB) in Northeast Russia (in yellow). The heavy dashed line represents the South Anyui Suture (SAS). South and west of the SAS and north of the OCVB and are the terranes of the Kolyma-Omolon Superterrane. To the north of the SAS is the Chukotka-Alaska terrane. To the south of the OCVB in Northeast Russia, the majority of the terranes accreted later than the formation of the OCVB. The location of the El'gygtgyn sampling area (Fig. 2) is also indicated. Base map from Nokelberg et al. (1996). The colors on the map represent: Siberian platform, purple; continental rocks, darker brown; major plutons, black; oceanic sediments (collapsed ocean basins), green; island arc rocks, pink; continental shelf deposits, blue; Quaternary cover, light brown (with lakes).

near Lake El'gygytgyn in northern Chukotka (Fig. 2). In this location the volcanic rocks of the OCVB lie directly on rocks ascribed to the Chukotka-Alaska terrane.

\section{Geologic setting}

The OCVB in the area around Lake Elgygytgyn (Fig. 2) is composed of subaerial calc-alkaline volcanic rocks including andesites, rhyolites, andesite-basalt sequences (Zonenshain et al., 1990), diorites, tonalites, granodiorites, quartz monzanites and granites (Belyi, 1994; Belyi and Belaya, 1998). Zonenshain et al. (1990) consider the belt to be the result of subduction occurring some $500 \mathrm{~km}$ to the southeast. The lake itself lies in a $3.58 \pm 0.04 \mathrm{Ma}$ impact structure (Layer, 2000) which melted and totally reset or partially reset some of the argon isotope systematics of nearby volcanic rocks.

There are three recognized basic-acidic sequences of volcanic rocks on the northern flank of the OCVB. The first cycle forms the lower Chaun (or Chaun'a) series (Belyi, 1994) exposed in the region as the Kalen'muvaam unit, and is widely exposed north of the Enmyvaamsk basin but was not sampled for this study. The second sequence includes, from bottom to top, the Pykarvaam, Voron'in and Koekvun' sequences (Belyi, 1988,1994) which form the upper components of the Chaun series of volcanic rocks. These lower two sequences are also termed the "external zone" by Belyi (1994) and are associated with the initiation of the OCVB. These rocks are considered by Belyi (1994) to be of Albian age (99.6-112.0 Ma) based on fossil plant material (note that all conversions of geologic ages to Ma are based on Gradstein et al., 2004). The Chaun series is separated by a major fault from the overlying volcanic rocks which comprise the late stage of development of the OCVB (Fig. 2).

Recently there have been several ${ }^{40} \mathrm{Ar} /{ }^{39} \mathrm{Ar}$ geochronologic studies of rocks from other locations within the Chaun group of the OCVB that place the age of the sequence as much younger than Albian. Kelley et al. (1999) reported ${ }^{40} \mathrm{Ar} /{ }^{39} \mathrm{Ar}$ isochron ages from the upper Chaun group (Pykarvaam, Voron'in and Koekvun' sequences) from Chukotka, northeast of Elgygytgyn of 87.0-88.7 Ma. Ispolatov et al. (2004) reported ages from the first cycle (lower Chaun Group) of 87.1 to $87.9 \mathrm{Ma}$, and one sample from a stratigraphic equivalent of the Koekvun unit to be $87.6 \mathrm{Ma}$ which are consistent with those from Kelley et al. (1999). Hourigan and Akinin (2004) reported ages of about 85.6 Ma from the Narauli suite of the Arman volcanic field further to the south in the Magadan region. Akinin and Khanchuk (2005) concluded that this suite is roughly correlative with the upper Chaun unit in our study area. Thus there appears to be a consensus among the recent geochronologic studies that the ${ }^{40} \mathrm{Ar} /{ }^{39} \mathrm{Ar}$ age for the Chaun group is post-Albian, probably Conacian to Santonian over great distances along the length of the Okhotsk Chukotka Volcanic Belt.

The overlying Ergyvaam, Emuneret and Enmyvaam suites represent the third volcanic sequence. The stratigraphic relationships of the individual suites are based on rare findings of fossil plants. The result of research on spores and ash complexes from sedimentary rocks in the Emnyvaam suite (analyses by B. V. Belaya) place the suite in the Early Senonian (Senonian is Post-Turonian to Pre-Danian, approx. 


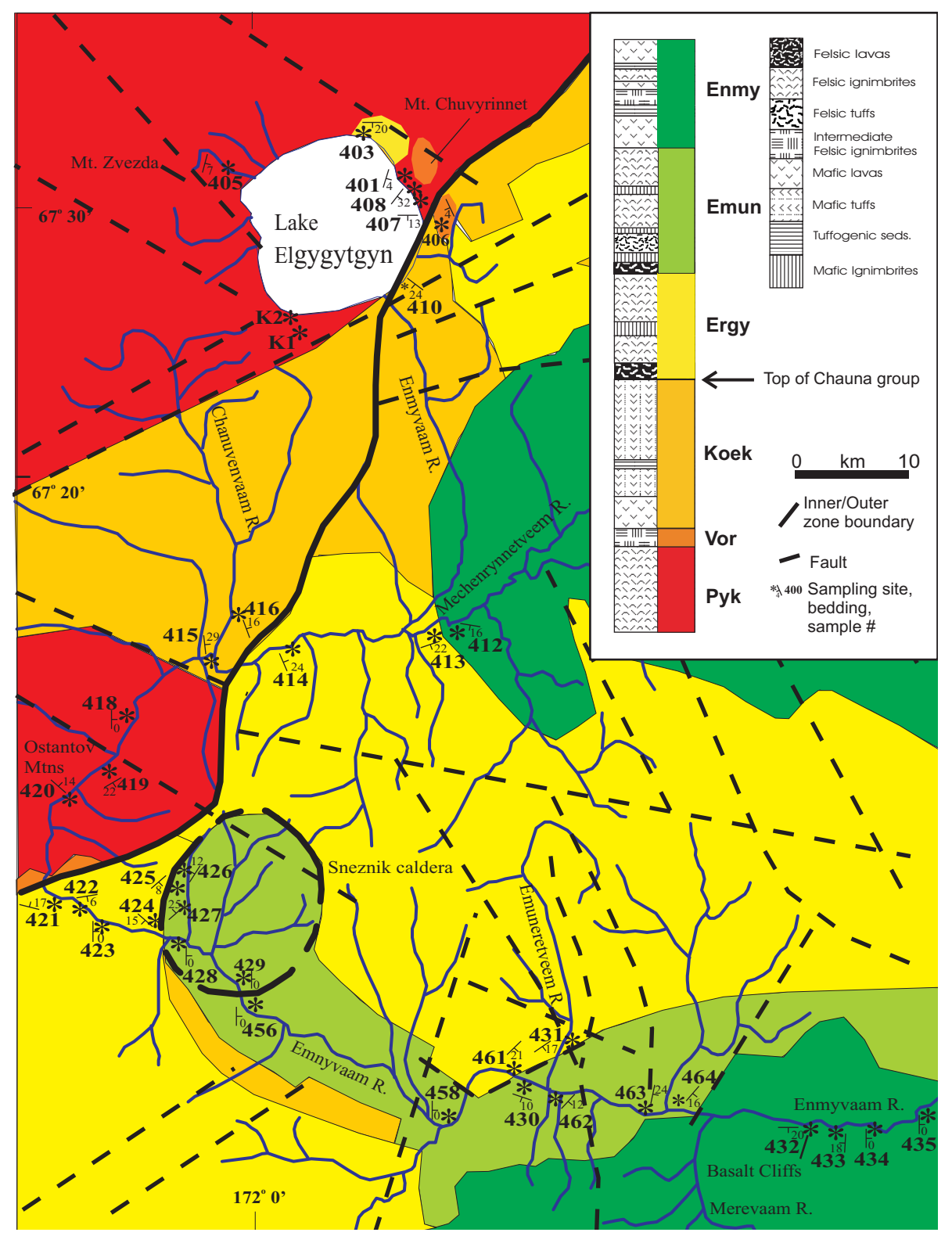

Fig. 2. Geologic map of the study area. The six volcanic suites sampled in this study are indicated and color coded together with the localities sampled (numbered stars). Base map compiled from Belyi (1994), Belyi and Belaya (1998) and Raikevitch (1995). Blue lines show rivers and tributaries, dashed lines mapped faults, and the black line with teeth a major thrust fault.

88.5-66.4 Ma). A number of researchers (Belyi, 1988; Samylina, 1975; Filippova, 1975, 1984; Schepetov, 1988, 1991) note that the ages of the rocks cannot be well determined from the plant fossils because of the large effects of local climatic conditions. For instance, Lebedev (1987) detected the Ust'-Emuneret floral complex with Quercus tschucotica in deposits of the Emuneret suite (middle fork of the Enmyvaam River), which indicates that the deposits are of Campanian age. However, Belyi (1988, p. 19) notes that complex variations of angiosperms disallow categorical conclusions about the age.
Hourigan and Akinin (2004) report ages of the upper units of the OCVB in the Magadan region (the Ola and Mygdykit Suites) ranging in age from 83.7 to $77.5 \mathrm{Ma}$. If these units are correlative to those in Chukotka, then they are consistent with the paleontological ages.

At El'gygytgyn, a complete sequence of the second and third cycles is preserved. The ${ }^{40} \mathrm{Ar} /{ }^{39} \mathrm{Ar}$ dating and the paleomagnetic reversal stratigraphy presented here allows a much more precise definition of relative stratigraphies for the volcanogenic-sedimentary formations, although questions as to the relative ages of the various formations still arise. 


\section{Paleomagnetic sampling}

In 1991, a set of oriented block samples was collected and prepared for paleomagnetic measurements and preliminary results published by Raikevitch (1995). We are not aware of any other published paleomagnetic measurements for the OCVB. An assortment of collections for palynological and paleo-floral evaluation was also made (Belyi and Belaya, 1998). Orientations for the paleomagnetic samples were determined with respect to geographic north as determined using a magnetic compass, compass corrections being made by taking magnetic bearings on known geographic features. The block samples were used to prepare $2 \times 2 \times 2 \mathrm{~cm}$ cubes for paleomagnetic studies, for determinations of the chemistry of the rocks, for the preparation of thin sections, and for radiometric age determinations. The area sampled displays a wide range of lithologies, including volcanogenicsedimentary rocks, ignimbrites and flow units, and the sampling was designed to investigate the magnetic record in each of them. At each locality (numbered stars in Fig. 2) between one and ten sites were sampled with at least three oriented blocks collected at each of site. These sites were selected based on estimates of the amount of time represented. For instance, multiple flow units, tuffs and ignimbrites that showed no evidence of significant time gaps were grouped as a single data point in Table 1, even though the sampling area may have covered many tens of meters. Whenever possible the orientation of paleo-horizontal was obtained for the local area around each sampling site, commonly determined from bedding attitudes, flow banding, and placement of welded tuffs in ignimbrites. When direct evidence of ancient horizontal was not available, bedding orientation was estimated using regional geology and aerial photographs. Details of the geology of the sampling sites, including sketches, maps and locations of the samples used in this study as well as the locations of fossil collections can be found in Belyi and Belaya (1998).

Sampling for field tests for magnetic stability were carried out wherever possible. These included collecting oriented samples from sites with variable bedding, noting the strikes and dips (for fold tests), from conglomerate clasts and from pebbles of exotic rocks included in the ignimbrites (both of which will give systematic magnetic directions if overprinted), and from dikes and their contact aureoles (which, if magnetized differently from the country rock indicate no overprinting since the dikes were emplaced). Along with these field-based stability tests, laboratory methods were also used to determine magnitude and direction of any viscous components of magnetization, and the separation of any other components of magnetization by means of progressive thermal and alternating field demagnetization.

The magnetic and paleomagnetic properties of the samples were studied using standard methods (Khramov, 1982), using spinner magnetometers (ION-1 and JR-4) in Magadan, Russia, and a $2 \mathrm{G}$ superconducting magnetometer in Fairbanks,
Alaska. Thermal demagnetization was done using a thermal demagnetizing attachment for the ION-1 spinner magnetometer, using an Aparing design of thermal unit in Magadan, and using a Schonstedt TSD-1 oven in Fairbanks. Alternating field demagnetization was also carried out using standard equipment.

\section{Geochronologic methods}

The new age determinations were carried out using ${ }^{40} \mathrm{Ar} /{ }^{39} \mathrm{Ar}$ methods at the Geochronology Laboratory of the Geophysical Institute of the University of Alaska (Layer et al., 1987; Layer, 2000). The results are summarized in Table 2 and Fig. 3 and the details may be found in Supplement (see http://www.stephan-mueller-spec-publ-ser. net/4/243/2009/smsps-4-243-2009-supplement.pdf). For the ${ }^{40} \mathrm{Ar} /{ }^{39} \mathrm{Ar}$ analyses, palomagnetic cores that were not subjected to any thermal demagnetization were used. The samples were crushed and sieved to a $250-500$ micron size fraction. Individual chips of the "whole rock" were hand-picked, and care was taken to avoid samples that had obvious signs of alteration or large phenocrysts. The monitor mineral MMhb1 (Samson and Alexander, 1987) with an age of 513.9 Ma (Lanphere and Dalrymple, 2000) was used to monitor neutron flux (and calculate the irradiation parameter, $J$ ). The samples and standards were wrapped in aluminum foil and loaded into aluminum cans of $2.5 \mathrm{~cm}$ diameter and $6 \mathrm{~cm}$ height. The samples were irradiated in the research reactor of McMaster University in Hamilton, Ontario, Canada for 20 megawatt hours.

Upon their return from the reactor, the samples were run either as small chips on a laser system or using a resistanceheating furnace. For the laser system, the samples and monitors were loaded into $2 \mathrm{~mm}$ diameter holes in a copper tray that was then loaded in an ultra-high vacuum extraction line where the monitors were fused, and samples heated, using a 6-W argon-ion laser and analyzed in a VG-3600 mass spectrometer following the technique described in York et al. (1981), Layer et al. (1987) and Layer (2000). Argon purification was achieved using a liquid nitrogen cold trap and a SAES Zr-Al getter at $400^{\circ} \mathrm{C}$.

For the furnace-heated samples, standards were fused and samples step heated up to $1600^{\circ} \mathrm{C}$ using an on-line Modifications Ltd. low-blank furnace connect to a Nuclide 6-60$\mathrm{SGA} 15 \mathrm{~cm}$ radius mass spectrometer. The basic sensitivity of the instrument, with the current extraction system (final cleanup volume) is $6.5 \times 10^{-15} \mathrm{~mol} / \mathrm{mV}$. Gas cleanup was accomplished using a two stage process and a 40-min heating cycle. Before a sample is introduced into the furnace, the furnace is heated to the lowest temperature step to be measured (usually $500^{\circ} \mathrm{C}$ ). This "sample" is measured as the system blank and the voltages for the various peaks are subtracted from the subsequent measurements. It was found that the furnace blank does not change substantially as the furnace is stepped up to $1600^{\circ} \mathrm{C}$, so we feel that the $500^{\circ} \mathrm{C}$ heating step 
Table 1. Paleomagnetic data from all localities.

\begin{tabular}{|c|c|c|c|c|c|c|c|c|c|c|c|}
\hline \multirow{2}{*}{$\begin{array}{l}\text { Top of section } \\
\text { Locality and rock type }\end{array}$} & \multirow[b]{2}{*}{$\mathrm{M}$} & \multirow[b]{2}{*}{$\mathrm{N}$} & \multirow{2}{*}{$\begin{array}{l}\text { Suscept } \\
10^{-5} \mathrm{SI}\end{array}$} & \multirow{2}{*}{$\begin{array}{l}\text { Intensity } \\
\times 10^{-3} \mathrm{~A} / \mathrm{m}\end{array}$} & \multirow[b]{2}{*}{ Strike/Dip } & \multicolumn{3}{|c|}{ Geographic } & \multicolumn{3}{|c|}{ Stratigraphic } \\
\hline & & & & & & $D g$ & $I g$ & $\kappa g$ & $D s$ & Is & $\kappa s$ \\
\hline \multicolumn{12}{|l|}{ Enmyvaam suite } \\
\hline 412 basalt & 25 & 5 & 75 & 1080 & $98 / 9$ & 268 & -76 & 14.3 & 301 & -75 & 18.7 \\
\hline 412 gravel & 1 & 2 & 86 & 7 & & & & & & & \\
\hline 412 clay & 25 & 2 & 29 & 7 & $101 / 23$ & 57 & 79 & 15.2 & 163 & 73 & 22 \\
\hline 412 basalt & 50 & 14 & 1520 & 3930 & & & & & & & \\
\hline 435 basalt & 5 & 5 & 3100 & 1100 & $0 / 0$ & 334 & 74 & 360 & 334 & 74 & 360 \\
\hline 434 dacite & 6 & 5 & 4000 & 1500 & $0 / 0$ & 310 & 72 & 32 & 310 & 72 & 36 \\
\hline 432 basalt & 20 & 3 & 1770 & 2930 & $90 / 21$ & 85 & 76 & 46 & 144 & 66 & 46 \\
\hline 432 conglom & 10 & 4 & 2500 & 6300 & $303 / 26$ & 26 & -4 & 1 & 25 & -30 & 1.2 \\
\hline 432 ignimbrite & 22 & 6 & 160 & $\mathbf{5 5 0}$ & $90 / 21$ & 22 & 75 & 62 & 143 & 81 & 64 \\
\hline 432 tuff sltstn & 33 & 8 & 145 & 10 & $90 / 20$ & 29 & 86 & 16 & 173 & 73 & 16 \\
\hline 432 ignimbrite & 55 & 11 & 1320 & 110 & $90 / 21$ & 51 & 79 & 10 & 148 & 74 & 10 \\
\hline 432 basalt & 12 & 3 & 2930 & 2700 & $84 / 22$ & 23 & 63 & 26 & 76 & 77 & 24 \\
\hline 432 intermed tuff & 50 & 7 & 750 & 177 & $97 / 22$ & 19 & 71 & 45 & 139 & 85 & 45 \\
\hline 432 acid tuff & 15 & 5 & 31 & 11 & $105 / 29$ & 21 & 68 & 32 & 178 & 83 & 36 \\
\hline 432 basic tuff & 40 & 14 & 1150 & $\mathbf{5 5 0}$ & $98 / 30$ & 39 & 76 & 50 & 165 & 71 & 56 \\
\hline 432 basalt & 100 & 10 & 2390 & 4400 & $99 / 29$ & 346 & 73 & 27 & 215 & 75 & 30 \\
\hline 433 basalt & 15 & 4 & 3500 & 3500 & $183 / 18$ & 95 & 74 & 60 & 256 & 88 & 68 \\
\hline 433 tuff siltstone & 2 & 2 & 2500 & 4200 & & & & & & & \\
\hline 433 ignimbrite & 2 & 2 & 370 & 250 & & & & & & & \\
\hline \multirow[t]{2}{*}{ Mean } & $N$ & $D g$ & $I g$ & $\kappa g$ & $R g$ & $\alpha 95$ & $D s$ & $I s$ & $\kappa s$ & $R s$ & $\alpha 95$ \\
\hline & 9 & 263.1 & 82.5 & 25.6 & 8.7 & 10.4 & 263.8 & 82.8 & 24.2 & 8.7 & 10.7 \\
\hline \multicolumn{12}{|l|}{ Emuneret suite } \\
\hline 464 ignimbrite & 14 & 4 & 2060 & 73100 & $39 / 16$ & 239 & 57 & 45 & 214 & 59 & 125 \\
\hline 463 ignimbrite & 12 & 6 & 1031 & 7060 & $11 / 24$ & 275 & 68 & 64 & 153 & 87 & 64 \\
\hline 462 ignimbrite & 33 & 9 & 133 & 4330 & $41 / 12$ & 90 & -79 & 101 & 14 & -82 & 68 \\
\hline 430 ignimbrite & 8 & 3 & 18 & 177 & $110 / 10$ & 70 & -76 & 22 & 50 & -68 & 25 \\
\hline 430 vitrophyre & 10 & 3 & 250 & 8060 & & & & & & & \\
\hline 430 tuff & 46 & 9 & 140 & 28 & & & & & & & \\
\hline 429 ignimbrite & 4 & 5 & 1100 & 300 & $0 / 0$ & 189 & -76 & 33 & 189 & -76 & 33 \\
\hline 429 basalt dike & 1 & 3 & 5600 & 5100 & $0 / 0$ & 293 & 72 & 58 & 293 & 72 & 58 \\
\hline 425 tuff & 3 & 3 & 8 & 1.4 & $47 / 8$ & 144 & -64 & 19.9 & 147 & -72 & 9.5 \\
\hline 425 vitrophyre & 11 & 3 & 20 & 50 & & & & & & & \\
\hline 426 vitrophyre & 16 & 3 & 25 & 80 & 211/12 & 136 & -76 & 44.4 & 129 & -64 & 74 \\
\hline 426 rhyolite & 2 & 3 & 15 & 6.4 & & & & & & & \\
\hline 427 ignimbrite & 3 & 3 & 900 & 1500 & $227 / 25$ & 338 & -75 & 346 & 111 & -78 & 742 \\
\hline 428 ignimbrite, vitro & 35 & 9 & 2400 & 15000 & $0 / 0$ & 177 & -85 & 170 & 177 & -85 & 170 \\
\hline 456 rhyolite & 15 & 7 & 73 & 910 & $0 / 0$ & 325 & -80 & 39 & 325 & -80 & 39 \\
\hline 458 ignimbrite & 7 & 3 & 1360 & 4690 & $\mathbf{0 / 0}$ & 84 & -82 & 61 & 84 & -82 & 61 \\
\hline \multirow[t]{2}{*}{ Mean } & $N$ & $D g$ & $I g$ & $\kappa g$ & $R g$ & $\alpha 95$ & Ds & $I s$ & $\kappa s$ & $R s$ & $\alpha 95$ \\
\hline & 7 & 22.3 & 71.7 & 12.3 & 6.5 & 17.9 & 40.7 & 74.5 & 13.6 & 6.6 & 16.9 \\
\hline \multicolumn{12}{|l|}{ Ergyvaam suite } \\
\hline 413 ignimbrite & 21 & 7 & 4000 & 2500 & $70 / 22$ & 47 & 70 & 33 & 106 & 67 & 32.7 \\
\hline 414 vitro,ignimbrite & 144 & 29 & 920 & 6160 & $338 / 24$ & 287 & 47 & 13.7 & 314 & 62 & $\mathbf{1 7 . 5}$ \\
\hline 403 ignimbrite & 9 & 4 & 215 & 36 & $90 / 20$ & 343 & 85 & 32.2 & 186 & 75 & 33.2 \\
\hline 424 ignimbrite & 7 & 4 & 2200 & 260 & $133 / 15$ & 41 & 53 & 380 & 40 & 68 & 725 \\
\hline 423 ignimbrite, dacite & 10 & 7 & 2100 & 9990 & $\mathbf{0 / 0}$ & 54 & 61 & 60 & 54 & 61 & 60 \\
\hline 422 ignimbrite & 5 & 3 & 1500 & 350 & $80 / 6$ & 32 & 63 & 150 & 41 & 67 & 154 \\
\hline 421 dacite & 7 & 4 & 2500 & 300 & $285 / 17$ & 35 & 72 & 95 & 26 & 56 & 100 \\
\hline 431 ignimbrite & 4 & 3 & 400 & 1400 & $54 / 17$ & 141 & 88 & 150 & 144 & 71 & 60 \\
\hline 461 sandstone & 23 & 5 & 1070 & 167 & $44 / 21$ & 325 & 83 & 59 & 128 & 76 & 62 \\
\hline \multirow[t]{2}{*}{ Mean } & $N$ & $D g$ & $I g$ & $\kappa g$ & $R g$ & $\alpha 95$ & $D s$ & $I s$ & $\kappa s$ & $R s$ & $\alpha 95$ \\
\hline & 3 & 78.3 & 3.0 & 7.7 & 2.7 & 48.0 & 354.8 & 84.3 & 83.3 & 3.0 & 13.6 \\
\hline
\end{tabular}


Table 1. Continued.

\begin{tabular}{|c|c|c|c|c|c|c|c|c|c|c|c|}
\hline \multirow{2}{*}{$\begin{array}{l}\text { Top of section } \\
\text { Locality and rock type }\end{array}$} & \multirow[b]{2}{*}{ M } & \multirow[b]{2}{*}{$\mathrm{N}$} & \multirow{2}{*}{$\begin{array}{l}\text { Suscept } \\
10^{-5} \mathrm{SI}\end{array}$} & \multirow{2}{*}{$\begin{array}{l}\text { Intensity } \\
\times 10^{-3} \mathrm{~A} / \mathrm{m}\end{array}$} & \multirow[b]{2}{*}{ Strike/Dip } & \multicolumn{3}{|c|}{ Geographic } & \multicolumn{3}{|c|}{ Stratigraphic } \\
\hline & & & & & & $D g$ & $I g$ & $\kappa g$ & $D s$ & Is & $\kappa s$ \\
\hline \multicolumn{12}{|l|}{ Koekvun suite } \\
\hline 415 tuff & 80 & 9 & 680 & 195 & $334 / 29$ & 235 & 66 & 21 & 99 & 84 & 56 \\
\hline 416 tuff & 320 & 13 & 1300 & 690 & $341 / 16$ & 270 & 70 & 17.4 & 317 & 83 & 31 \\
\hline 410 ignimbrite & 6 & 4 & 1000 & 1500 & $129 / 24$ & 21 & 56 & 150 & 348 & 77 & 411 \\
\hline \multirow[t]{2}{*}{ Mean } & $N$ & $D g$ & $\operatorname{Ig}$ & $\kappa g$ & $R g$ & $\alpha 95$ & Ds & Is & $\kappa s$ & $R s$ & $\alpha 95$ \\
\hline & 3 & bf78.3 & 3.0 & 7.7 & 2.7 & 48.0 & 354.8 & 84.3 & 83.3 & 3.0 & 13.6 \\
\hline \multicolumn{12}{|l|}{ Voron'in suite } \\
\hline 406 ignimbrite & 9 & 5 & 3500 & 6900 & $156 / 4$ & 260 & 83 & 527 & 255 & 79 & 527 \\
\hline \multirow[t]{2}{*}{ Mean } & $N$ & $D g$ & $I g$ & $\kappa g$ & $R g$ & $\alpha 95$ & Ds & Is & $\kappa s$ & $R s$ & $\alpha 95$ \\
\hline & 1 & 260.0 & 83.0 & & & & 255.0 & 79.0 & & & \\
\hline \multicolumn{12}{|l|}{ Pyrkarvaam suite } \\
\hline 408 ignimbrite & 21 & 8 & 150 & 250 & $36 / 32$ & 308 & 45 & 52 & 313 & 77 & 209 \\
\hline 407 ignimbrite & 16 & 6 & 1200 & 2050 & $90 / 13$ & $\mathbf{0}$ & 79 & 122 & 177 & 88 & 134 \\
\hline 401 ignimbrite & 6 & 3 & 325 & 427 & $376 / 4$ & 288 & 70 & 24 & 283 & 74 & 23.2 \\
\hline 418 ignimbrite & 4 & 3 & 2000 & 880 & $0 / 0$ & 1 & 81 & 244 & 1 & 81 & 244 \\
\hline 419 ignimbrite & 8 & 5 & 220 & 75 & $58 / 22$ & 335 & 80 & 22 & 142 & 78 & 25 \\
\hline 420 ignimbrite & 3 & 3 & 50 & 50 & $313 / 14$ & 183 & 78 & 44 & 95 & 81 & 18 \\
\hline 405 ignimbrite & 4 & 3 & 2180 & 2560 & $14 / 7$ & 262 & 65 & 40 & 255 & 71 & 41 \\
\hline \multirow{2}{*}{ Mean } & $N$ & $D g$ & $\operatorname{Ig}$ & $\kappa g$ & $R g$ & $\alpha 95$ & Ds & Is & $\kappa s$ & $R s$ & $\alpha 95$ \\
\hline & 6 & 305.7 & 72.9 & 20.9 & 5.8 & 15.0 & 278.2 & 83.9 & 41.4 & 5.9 & 10.5 \\
\hline \multicolumn{12}{|l|}{ Mean of all selected data } \\
\hline & $N$ & $D g$ & $\operatorname{Ig}$ & $R g$ & $\kappa g$ & $\alpha 95$ & Ds & Is & $R g$ & $\kappa g$ & $\alpha 95$ \\
\hline & 40 & 350 & 81.5 & 37.83 & 18.0 & 5.5 & 238.3 & 89.8 & 38.24 & 22.1 & 4.9 \\
\hline
\end{tabular}

with no sample is an acceptable correction for the system blank. Following the heating step, the gas was released from the charcoal for $10 \mathrm{~min}$ and cleaned up using a SAES ST-101 getter.

The argon isotopes measured were corrected for system blank and mass discrimination, as well as calcium, potassium and chlorine interference reactions following procedures outlined in McDougall and Harrision (1999). Mass discrimination was monitored by running both calibrated air shots and a zero-age glass sample. These measurements were made on a weekly to monthly basis to check for changes in mass discrimination. Age interpretations (discussed below) were made based on examination of the age, $\mathrm{Ca} / \mathrm{K}$ and $\mathrm{Cl} / \mathrm{K}$ spectra and from inverse isochrons. Because the samples were "whole-rocks", several mineral phases might be present, and these are represented by different parts of the spectra. Plateau and isochron ages were calculated for samples with three or more consecutive fractions constituting $>50 \% 39 \mathrm{Ar}$ release, with ages that lie within 2- $\sigma$ of one another (for plateaus) or of the regression line (for isochrons). This scatter is generally expressed as the Mean Square Weighted Deviates (MSWD) or probability (Table 2). For calculations where $p>0.05$ $($ MSWD $\lesssim 2.5)$ plateau or isochron ages are quoted. For analyses that do not meet these criteria, weighted mean ages of "plateau-like" fractions, or errorchrons are reported. All ages are quoted at the $1-\sigma$ level. For most samples, we interpret the "groundmass" part of the release to be the most representative of the primary cooling age of the sample. Although several samples do not show well-constrained plateaus or isochrons, analyses of samples from the same localities (e.g. 406 or 430) are internally consistent and, for the most part, stratigraphically consistent as well.

\section{Geochronology and paleomagnetism for six OCVB suites}

The study reported here involves samples from six suites. The stratigraphic order of these suites is well established; however the details of the relationships between them are seldom clear. The following descriptions start with the uppermost suite.

\subsection{The Enmyvaam suite}

\subsubsection{Sampling localities}

The Enmyvaam suite (Enmy in Fig. 2) is best developed along the middle fork of the Enmyvaam River (Belyi, 1988). Outcrops begin 4-5 km above confluence with the Merevaam River, where the suite lies conformably upon deposits of the 

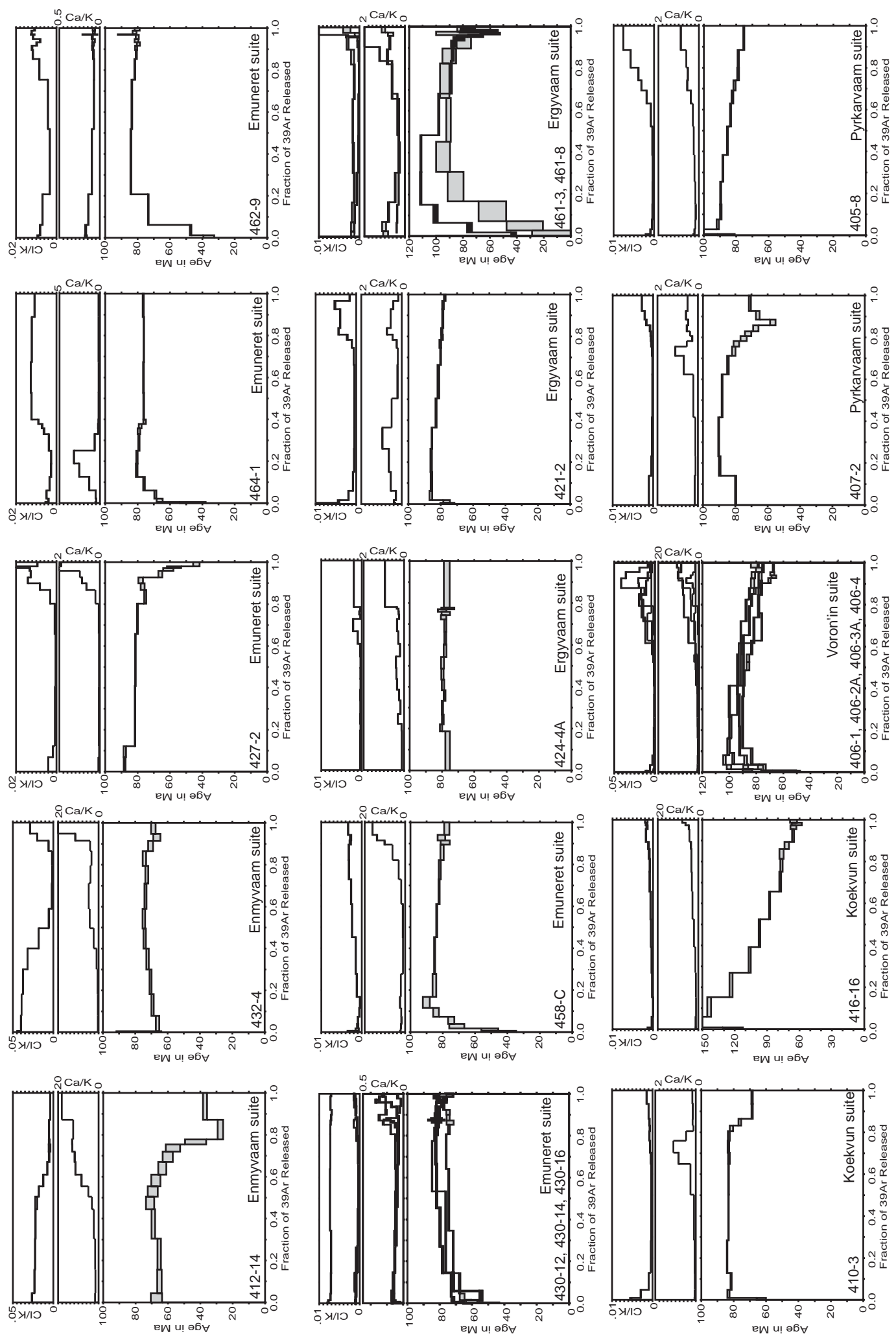

Fig. 3. ${ }^{40} \mathrm{Ar} /{ }^{39} \mathrm{Ar}$ age, $\mathrm{Ca} / \mathrm{K}$ and $\mathrm{Cl} / \mathrm{K}$ spectra for whole rock samples from the El'gygytgyn region. See Table 2 for interpretations. 
Table 2. ${ }^{40} \mathrm{Ar} /{ }^{39} \mathrm{Ar}$ ages of El'gygytgyn volcanics.

\begin{tabular}{|c|c|c|c|c|c|}
\hline Sample & $\begin{array}{l}\# \text { of } \\
\text { steps }\end{array}$ & $\begin{array}{l}\text { Integrated } \\
\text { ages (Ma) }\end{array}$ & $\begin{array}{l}\text { Plateau }(\mathrm{P}) \text { or } \\
\text { Weighted } \\
\text { Mean }(\mathrm{W}) \\
\text { age }(\mathrm{Ma})\end{array}$ & $\begin{array}{l}\text { Isochron or } \\
\text { Errorchron } \\
\text { age }(\mathrm{Ma})\end{array}$ & Comments \\
\hline \multicolumn{6}{|c|}{ Enmyvaam suite } \\
\hline $412-14$ & $13(\mathrm{~F})$ & $58.3 \pm 0.6$ & $67.0 \pm 0.9(P)$ & $67.8 \pm 1.1$ & 8 fractions, $67 \%$ gas release, $\mathrm{MSWD}=1.8, p=0.08$ \\
\hline $432-4$ & $13(\mathrm{~F})$ & $71.7 \pm 0.4$ & $73.7 \pm 0.5(P)$ & - & 6 fractions, $57 \%$ gas release, $\mathrm{MSWD}=1.3, p=0.28$ \\
\hline \multicolumn{6}{|c|}{ Emuneret suite } \\
\hline $427-2$ & $13(\mathrm{~F})$ & $79.8 \pm 0.3$ & $\mathbf{8 1 . 2} \pm \mathbf{0 . 8}(\mathrm{W})$ & $80.8 \pm 0.7$ & 3 fractions, $68 \%$ gas release, $\mathrm{MSWD}=11.3, p=0.00$ \\
\hline $464-1$ & $14(\mathrm{~L})$ & $76.5 \pm 0.2$ & $76.3 \pm 0.2(P)$ & $75.7 \pm 0.9$ & 5 fraction, $62 \%$ gas release, $\mathrm{MSWD}=0.5 . p=0.76$ \\
\hline $462-9$ & $14(\mathrm{~L})$ & $79.7 \pm 0.3$ & $81.2 \pm 0.3(\mathrm{~W})$ & $80.8 \pm 0.4$ & 8 fraction isochron ${ }^{40} \mathrm{Ar} /{ }^{36} \mathrm{Ar}_{\mathrm{i}}=283 \pm 38, \mathrm{MSWD}=0.7, p=0.91$ \\
\hline $430-12$ & $13(\mathrm{~L})$ & $73.2 \pm 0.3$ & $75.2 \pm 0.3(\mathrm{~W})$ & $74.2 \pm 1.2$ & model age of $77 \mathrm{Ma} 8$ fraction plateau $65 \%$ gas release. \\
\hline $430-14$ & $14(\mathrm{~L})$ & $79.1 \pm 0.3$ & $82.2 \pm 0.5(W)$ & $84.1 \pm 0.4$ & 9 fractions, $22.5 \%$ gas release, $\mathrm{MSWD}=0.9, p=0.69$ \\
\hline $430-16$ & $13(\mathrm{~F})$ & $78.5 \pm 0.3$ & $81.9 \pm 0.5(\mathbf{P})$ & - & 5 fractions, $50 \%$ gas release, $\mathrm{MSWD}=2.6, p=0.05$ \\
\hline $458-\mathrm{C}$ & $15(\mathrm{~L})$ & $82.2 \pm 0.4$ & - & $\mathbf{8 3 . 4} \pm \mathbf{0 . 7}$ & 7 fraction errorchron ${ }^{40} \mathrm{Ar} /{ }^{36} \mathrm{Ar}_{\mathrm{i}}=302, \mathrm{MSWD}=9.1, p=0.00$ \\
\hline \multicolumn{6}{|c|}{ Ergyvaam suite } \\
\hline $424-4 \mathrm{~A}$ & $16(\mathrm{~L})$ & $78.1 \pm 0.7$ & $78.2 \pm 0.7(\mathbf{P})$ & $79.6 \pm 0.4$ & 12 fractions, $67 \%$ gas release, $\mathrm{MSWD}=1.1, p=0.63$ \\
\hline $421-2$ & $15(\mathrm{~L})$ & $82.3 \pm 0.3$ & $85.8 \pm 0.3(\mathrm{~W})$ & $85.9 \pm 0.6$ & 6 fraction errorchron ${ }^{40} \mathrm{Ar} /{ }^{36} \mathrm{Ar}_{\mathrm{i}}=290 \pm 7, \mathrm{MSWD}=5.7, p=0.00$ \\
\hline $461-3$ & $16(\mathrm{~L})$ & $96.4 \pm 0.4$ & - & $89.5 \pm 2.4$ & 6 fraction errorchron ${ }^{40} \mathrm{Ar} /{ }^{36} \mathrm{Ar}_{\mathrm{i}}=800, \mathrm{MSWD}=9.1, p=0.00$ \\
\hline $461-8$ & $12(\mathrm{~L})$ & $82.2 \pm 2.0$ & $89.8 \pm 1.9(\mathbf{P})$ & $91.3 \pm 2.1$ & 8 fractions, $84 \%$ gas release, $\mathrm{MSWD}=1.3, p=0.27$ \\
\hline \multicolumn{6}{|c|}{ Koekvun suite } \\
\hline $410-3$ & $13(\mathrm{~F})$ & $80.8 \pm 0.3$ & $\mathbf{8 3 . 1} \pm \mathbf{0 . 4}(\mathrm{P})$ & $83.1 \pm 0.5$ & 6 fractions, $55 \%$ gas release, $\mathrm{MSWD}=0.8, p=0.64$ \\
\hline $416-16$ & $15(\mathrm{~L})$ & $99.9 \pm 0.5$ & - & $\mathbf{8 2 . 5} \pm 1.5$ & 6 fraction isochron ${ }^{40} \mathrm{Ar} /{ }^{36} \mathrm{Ar}_{\mathrm{i}}=371 \pm 3.6, \mathrm{MSWD}=1.8, p=0.11$ \\
\hline \multicolumn{6}{|c|}{ Voron'in suite } \\
\hline $406-1$ & $13(\mathrm{~L})$ & $90.1 \pm 0.3$ & & $90.3 \pm 4.6$ & 5 fraction errorchron ${ }^{40} \mathrm{Ar} /{ }^{36} \mathrm{Ar}_{\mathrm{i}}=435 \pm 71, \mathrm{MSWD}=10.5, p=0.00$ \\
\hline $406-2 \mathrm{~A}$ & $13(\mathrm{~L})$ & $89.6 \pm 0.3$ & $92.7 \pm 1.1$ & $92.8 \pm 1.3$ & 5 fraction errorchron ${ }^{40} \mathrm{Ar} /{ }^{36} \mathrm{Ar}_{\mathrm{i}}=285 \pm 25, \mathrm{MSWD}=15.3, p=0.00$ \\
\hline 406-3A & $13(\mathrm{~L})$ & $85.1 \pm 0.4$ & $89.9 \pm 0.6$ & $89.7 \pm 1.2$ & 5 fraction errorchron ${ }^{40} \mathrm{Ar} /{ }^{36} \mathrm{Ar}_{\mathrm{i}}=281 \pm 6, \mathrm{MSWD}=12.6, p=0.00$ \\
\hline \multirow[t]{2}{*}{$406-4$} & $13(\mathrm{~F})$ & $87.1 \pm 0.3$ & & $\mathbf{8 8 . 3} \pm 3.7$ & 6 fraction errorchron ${ }^{40} \mathrm{Ar} /{ }^{36} \mathrm{Ar}_{\mathrm{i}}=1246 \pm 451, \mathrm{MSWD}=5.8, p=0.00$ \\
\hline & & & AVERAGE & $91.0 \pm 0.9$ & \\
\hline \multicolumn{6}{|c|}{ Pyrkarvaam suite } \\
\hline $407-2$ & $13(\mathrm{~F})$ & $82.3 \pm 0.3$ & $\mathbf{8 8 . 5} \pm \mathbf{1 . 7}(\mathbf{W})$ & - & 4 fractions, $57 \%$ gas release, $\mathrm{MSWD}=36.2, p=0.00$ \\
\hline $405-8$ & $13(\mathrm{~F})$ & $84.5 \pm 0.3$ & - & 88.6 \pm 0.9 & 8 fraction isochron ${ }^{40} \mathrm{Ar} /{ }^{36} \mathrm{Ar}_{\mathrm{i}}=1075 \pm 198, \mathrm{MSWD}=2.4, p=0.05$ \\
\hline
\end{tabular}

* Laser (L) or furnace (F) run; Samples run using standard MMhb-1 with an age of 513.9 and calculated using constants of Steiger and Jaeger (1977). All errors are $\pm 1 \sigma$. Bold ages are those for which we have the greatest confidence. MSWD: Mean square weighted deviates, $p$ : probability

Emuneret suite. The section contains a continuous stratigraphy with a thickness of around $350 \mathrm{~m}$. The greater part of the section consists of basalt flows with a thickness of about $100 \mathrm{~m}$ informally called the Basalt Cliffs section (see Fig. 2, locality 432). This whole section has been studied in detail, using petrochemistry and sampling of the fossil flora. A more detailed description with sketches of sampling sites can be found in the work of Belyi (1988) and Belyi and Belaya (1998). The flows were erupted during the final stage of the third basic-acidic sequence of volcanism (Drabkin, 1970a, b). The basalts are overlain by tuffs of basic and acidic composition, with thicknesses up to $100 \mathrm{~m}$. Lying above the tuffs is a $12 \mathrm{~m}$ thick basalt flow with clearlydefined upper and lower surfaces. Above this flow lies a com- plexly structured mass of primarily acidic rocks, with the lower part (approximately $55 \mathrm{~m}$ thick) consisting of coarse light gray ignimbrites, the middle part (approx. $30 \mathrm{~m}$ thick) consisting of siltstones and shales with interbeds of coal and mudstone, and the upper part (approx. $20 \mathrm{~m}$ thick) consisting of pink slightly welded ignimbrites of acidic composition. In this mass of acidic rocks is a $10 \mathrm{~m}$ thick conglomerate, with clasts of basic and acidic rocks. The Basalt Cliffs section is completed by a flow of andesitic basalt with a thickness of about $20 \mathrm{~m}$. The beds dip to the south at an angle of $15-25^{\circ}$. In the upper reaches of the Enmyvaam River along its left tributary, the Mechekrynnetveem River, the Enmyvaam deposits form part of the Mechekrynnetveem paleobasin. The basin is represented by basalts and mudstones, 
in which fossil plant detritus and coalified wood have been found. The base of the Emnyvaam suite in this area is in fault contact with ignimbrites of the Ergyvaamsk suite. The regional dip in this area is at an angle of $10-20^{\circ}$ to the southeast.

\subsubsection{Paleomagnetism}

Seventy oriented block samples were taken at regular intervals throughout the entire thickness of the section at the Basalt Cliffs (Fig. 2, locality 432). In addition, samples of basalts and dacites were collected from higher levels of the suite (Fig. 2, localities 434, 435). In the region of the Mechekrynnetveem basin, a detailed study of one section was carried out (Fig. 1, locality 412) which involved sampling of massive basalts, their overlying shales with an upper band of gravel deposits and conglomerates, and also the highest horizon of pillow basalts. The total thickness of the studied section was about $90 \mathrm{~m}$.

The time represented by the combined sampling sites, which are widely distributed among the multiple stacked flows and interbedded fossilliferous sediments at both the Basalt Cliffs (locality 432) and the Mechekrynnetveem (locality 412) sections, is consistent with the roughly $6 \mathrm{Ma}$ indicated by the geochronology and the magnetostratigarphy described below. In both of these sections the regional and local bedding attitudes are well determined from flows and bedded units which can be traced over tens to hundreds of meters (Table 1 and Fig. 2).

Using thermal demagnetization techniques to determine the magnetic components of the basalts, dacites, and ignimbrites it is evident that the magnetization is represented by a single component which gradually decreases in intensity without any change in direction. Total destruction of magnetization occurs at a temperature of $580^{\circ} \mathrm{C}$, indicating magnetite as the primary magnetic carrier. In tuffs, tuffaceous sandstones, and tuffaceous siltstones, magnetite is again the magnetic carrier. However, along with the primary magnetization there is up to $50 \%$ viscous magnetization, removed by heating to $150-200^{\circ} \mathrm{C}$.

A conglomerate test of the magnetic stability was carried out on the Basalt Cliffs section (locality 432) using a conglomerate which underlies the upper flow of andesitic basalt. Four oriented pebbles of volcanic rocks were measured, and gave a value of kappa of less than 1 . This indicates the absence of baking of these rocks by the overlying andesitic basalts. Similarly, in the Mechekrynnetveem basin (locality 412), oriented samples of pebbles from the conglomerate were measured, again giving a value of kappa of less than 1 . This indicates that the conglomerates were not remagnetized after deposition. In contrast, a 0.3-m thick bed of lithified gravel between the conglomerate and the basalts has the same reversed direction of magnetization as the immediately overlying basalts. The magnetization directions in the lithified gravels are stable up to temperatures of $550^{\circ} \mathrm{C}$. This leads to the conclusion that the flows and sediments have not been subjected to any regional remagnetization events, and except for the gravels in the thermal contact zone associated with the overlying flow units, they all record the magnetic field at the time of original deposition or cooling. In summary, the pillow basalts in the upper part of the suite in the Mechekrynnetveem basin (locality 412, see Table 1), together with the gravel beds baked by them, indicate reversed polarities with normal polarities making up the entire lower part of the section exposed in the middle fork of the Enmyvaam River. A reversal test applied to these data is positive (Table 3).

\subsubsection{Geochronology}

Two samples were dated from this suite by the ${ }^{40} \mathrm{Ar} /{ }^{39} \mathrm{Ar}$ method. The first is from the Mechekrynnetveem basin (41214 ) and the second is from further down the section from the Basalt Cliffs section (432-4). The age spectrum from a furnace run of 412-14 exhibits a flat plateau at $67.0 \pm 0.9 \mathrm{Ma}$ $(1-\sigma)$ for the first $67 \%$ of gas release (Fig. 3). This age is identical to, but slightly more precise than the isochron age for the same fractions. At higher extraction temperature temperatures, the age drops off. This part of the release also correlates with higher $\mathrm{Ca} / \mathrm{K}$ and lower $\mathrm{Cl} / \mathrm{K}$ ratios and we interpret this to represent degassing of a partially altered phenocryst phase (probably plagioclase). A furnace run on sample 432-4 shows similar, but not as pronounced behavior. The plateau age of this sample is $73.7 \pm 0.5 \mathrm{Ma}$, and is consistent with its isochron age. These ages are consistent with K-Ar ages repoted by Belyi and Belaya (1998) which range from 81 to $73 \mathrm{Ma}$.

\subsection{The Emuneret suite}

\subsubsection{Sampling localities}

Deposits of the Emuneret suite (Emun in Fig. 2) are exposed in the middle fork of the Enmyvaam river, from the confluence of Alunitovyi Creek (not shown) about $5 \mathrm{~km}$ above its confluence with the Merevaam River where a clear stratigraphic succession of the Enmyvaamsk suite is seen in a shoreline outcrop. The Emuneret suite is composed of various rock complexes: ignimbrites of rhyolitic composition with dikes and bedded vitrophyres, ash and lithoclastic tuffs, and flows and dikes of rose-colored rhyolites. The deposits of this suite are cut by fractures along which dikes of basic composition have been intruded. At the confluence of the Emuneretveem River, there is a section of tuffaceous sandstones and siltstones, the latter containing a localized flora of the unique Ust'-Emuneret floral complex, indicating a Campanian age, which is in accord with the Argon/Argon ages discussed below (Lebedev, 1987). Rocks of the Emuneret suite are truncated by the formation of the Snezhninsk caldera, whose borders contact deposits of the Pykarvaam, Koekvun', and Ergyvaam Suites. There is little geological evidence on 
Table 3. Reversal test (following McFadden and McElhinny, 1990).

\begin{tabular}{lllllllllll}
\hline & $R-$ & $N-$ & $D-$ & $J-$ & $R+$ & $N+$ & $D+$ & $J+$ & $Y c$ & $Y o$ \\
\hline Enmyvaam & 6.65 & 7 & 121 & 75 & 15.31 & 16 & 163 & 73 & 14.95 & 11.49 \\
Emuneret & 51.18 & 63 & 208 & 75 & 9.6 & 10 & 198 & 78 & 20.78 & 3.79 \\
\hline
\end{tabular}

$R-(R+)$ are lengths of reversed (normal) vectors; $N-(N+)$ the number of reversed (normal) samples; $D-(D+)$ the mean declination of reversed (normal) samples: $J-(J+)$ the mean inclination of reversal (normal) samples; $Y c=$ critical angle, $Y o=$ obtained angle. $Y c>Y o$, thus the reversal test is positive.

which to base estimates of the time represented by the sampled sections due to the geological complexity of some of the sample sites. Local and regional bedding attitudes were from both flows and associated sediments indicating that the rocks in the Emuneret suite in the vicinity of the caldera are subhorizontal, the inclination of the bedding not exceeding $5^{\circ}$. At the confluence of the Emuneretveem River and up to the contact with deposits of the Enmyvaamsk suite, rocks are inclined to the southeast at angles of $15-30^{\circ}$.

\subsubsection{Paleomagnetism}

Oriented samples from deposits of the Emuneret suite were taken from six localities, five of them (localities 425-429) in the vicinity of the Snezhninsk caldera, and one (locality 430) near the confluence of the Emuneretveem River, far from the caldera (see Fig. 2). The magnetic characteristics of the rocks in this suite are diverse, ranging from practically nonmagnetic (lithoclastic tuffs, locality 425) to strongly magnetic ignimbrites, (locality 428, Table 1).

A distinguishing characteristic of the ignimbrites at localities 427, 428, and 429 is the presence of a magnetic fraction of host-rock iron, which, judging from results of thermal demagnetization, carry up to $40 \%$ of the residual magnetism. The direction of magnetization is similar to that seen in related rock sections, thus the presence of the iron does not affect the recorded field. Similarly, demagnetization to a temperature of $620^{\circ} \mathrm{C}$ does not change the direction of the resultant vector, and is still below the blocking temperature. The presence of host-rock iron is supported by results of research on the composition of the ferromagnetic fraction, using a "Kamebaks" microprobe. The presence of alpha-Fe in rocks of ignimbritic composition in the area of the OCVB is discussed by Filimonova (1985). In vitrophyres and rhyolites, and also in the ignimbrites of locality 430, only magnetite is found in the composition of the magnetic carriers. The presence of alpha iron appears to be a unique trait of ignimbrites in the caldera complex.

The magnetization in the rhyolites, vitrophyres, and ignimbrites is considered to be primary with a small fraction of viscous magnetization. Thermal demagnetization decreases the scatter of the vector directions. Some difficulty was encountered in the separation of the characteristic direction of magnetization in the lithoclastic tuffs (locality 430), in which a large (up to $70 \% J_{\mathrm{NRM}}$ ) viscous magnetization exists along with the primary magnetization. Heating the rocks up to $300^{\circ} \mathrm{C}$ results in the separation of the stable magnetization which has a direction close to the magnetization of overlying vitrophyres and ignimbrites. That the characteristic magnetization is primary is indicated at locality 429, where a set of ignimbrites is intruded by several vertical dikes of basalt. Paleomagnetic samples were collected across one of the dikes out to a maximum $8 \mathrm{~m}$ distance from the dike contact. The basalt dike has a positive (normal) magnetization (Fig. 4, sample 429-3) as do ignimbrites from the contact zone (Fig. 4, sample 429-5). At a distance of $1 \mathrm{~m}$ from the contact, the ignimbrites show a positive direction of magnetization, which is destroyed upon heating to $450^{\circ} \mathrm{C}$, leaving a negative component (Fig. 4 sample 429-6) At a distance of $8 \mathrm{~m}$ from the contact, the ignimbrites show negative (reversed) magnetization directions with a small positive component, which is destroyed upon heating to $150^{\circ} \mathrm{C}$. (Fig. 4 , sample 429-7).

It follows that the ignimbrites in the contact zone acquired partial TRM due to heating by the dikes during a time of normal polarity. It is clear that these deposits of the Emuneret suite, as well as the Snezhninsk caldera and its surroundings, have a reversed primary magnetization with steep angles of inclination indicating a high paleolatitude (see Table 1).

\subsubsection{Geochronology}

Five localities were sampled for ${ }^{40} \mathrm{Ar} /{ }^{39} \mathrm{Ar}$ dating. Sample 427-2 (Table 2) is from the reversed section of Snezhninsk Caldera. The age spectrum shows a slight amount of excess argon for the first two steps, then three fractions with a weighted mean age of $81.2 \pm 0.8 \mathrm{Ma}$ and then younger ages corresponding to a high $\mathrm{Ca} / \mathrm{K}$ phase.

Four sites were sampled from the Emuneretveem River exposure. Sample 464-1 is from the normal polarity interval at the top of the section (Fig. 3). It has a well-defined plateau age of $76.3 \pm 0.2 \mathrm{Ma}$. Sample $462-9$, further down the section has an age spectrum that shows evidence of argon loss. The spectrum steps up to a consistent age, which has a isochron age of $80.8 \pm 0.4 \mathrm{Ma}$. Four samples were analysed from site 430. All show varying amounts of argon loss. Three of the four samples have well-defined ages with an average of $81.8 \pm 0.3 \mathrm{Ma}$. Sample $458-\mathrm{C}$ is from the lower part of the Emuneretveem River section. It has an isochron age of $83.4 \pm 0.7 \mathrm{Ma}$. 


\subsection{The Ergyvaam suite}

\subsubsection{Sampling localities}

The deposits of the Ergyvaam suite, (Ergy in Fig. 2) which mark the beginning of the third major cycle in the northern part of the OCVB (Drabkin, 1970a, b) are exposed in the upper reaches of the Enmyvaam River between two tributaries, the Mechekrynnetveem River and the Chanuvenvaam River (see Fig. 2). In this outcrop area, deposits are represented by ignimbrites of acidic composition (localities 413, 414), which include thick (up to $60 \mathrm{~m}$ ) flows of black vitrophyres of rhyolitic composition, often with columnar jointing. Along the middle fork of the Enmyvaam River, the deposits of this suite appear to overlie deposits of the Koekvun'sk suite and stretch along the river from the confluence of the Kuivyrinnetveem River (not shown) almost to the confluence of Alunitovyi creek (not shown) just west of Snezhninsk Caldera (see Fig. 2, localities 421-424.) Here, the rocks consist of gray dacite flows in the lower part of the suite (localities 421), which are replaced by pink, light gray ignimbrites of acidic composition higher in the section. In contrast to the ignimbrites of the Pykarvaam suite, these contain fragments of basic rocks. The Ergyvaam suite was sampled at eight widely distributed sample sites, each of which could represent a relatively small time span. However, the sample site distribution make it unlikely that the individual sites overlap, thus collectively they give a time-averaged paleomagnetic field direction.

\subsubsection{Paleomagnetism}

Samples of Ergyvaam deposits were collected from various rock complexes (ignimbrites, vitrophyres, and dacites) from seven localities. The rocks were strongly magnetic, with magnetic susceptibilities higher than $1000 \times 10^{-3} \mathrm{~A} / \mathrm{m}$ and with high residual magnetizations in the vitrophyres and ignimbrites of the Zherlov facies (locality 423). The ratio of the magnetization to the magnetic susceptibility, the $Q$ factor, in these rocks was higher than 9 as can be seen from Table 1 , while at other localities the magnetization of was much lower, with $Q$ factors less than 1 . This indicates that there is a wide variation in the minerals carrying the magnetization.

Thermal demagnetization showed that residual magnetization in all rock complexes in the Ergyvaam suite was formed in a geomagnetic field of normal polarity, mostly carried by a thermal remanent magnetization (TRM). This is especially marked in vitrophyres, whose average direction of magnetization shows very little change with thermal demagnetization from $20^{\circ}$ to $550^{\circ} \mathrm{C}$, while the value of kappa increases from 30 to 68 by $550^{\circ} \mathrm{C}$. In these samples complete destruction of the magnetization occurs at $580^{\circ} \mathrm{C}$, indicating that magnetite is the magnetic carrier. In dacites and ignimbrites of dacitic composition (localities 421, 422, 424), up to $50 \%$ of the NRM is a viscous magnetization which is destroyed on
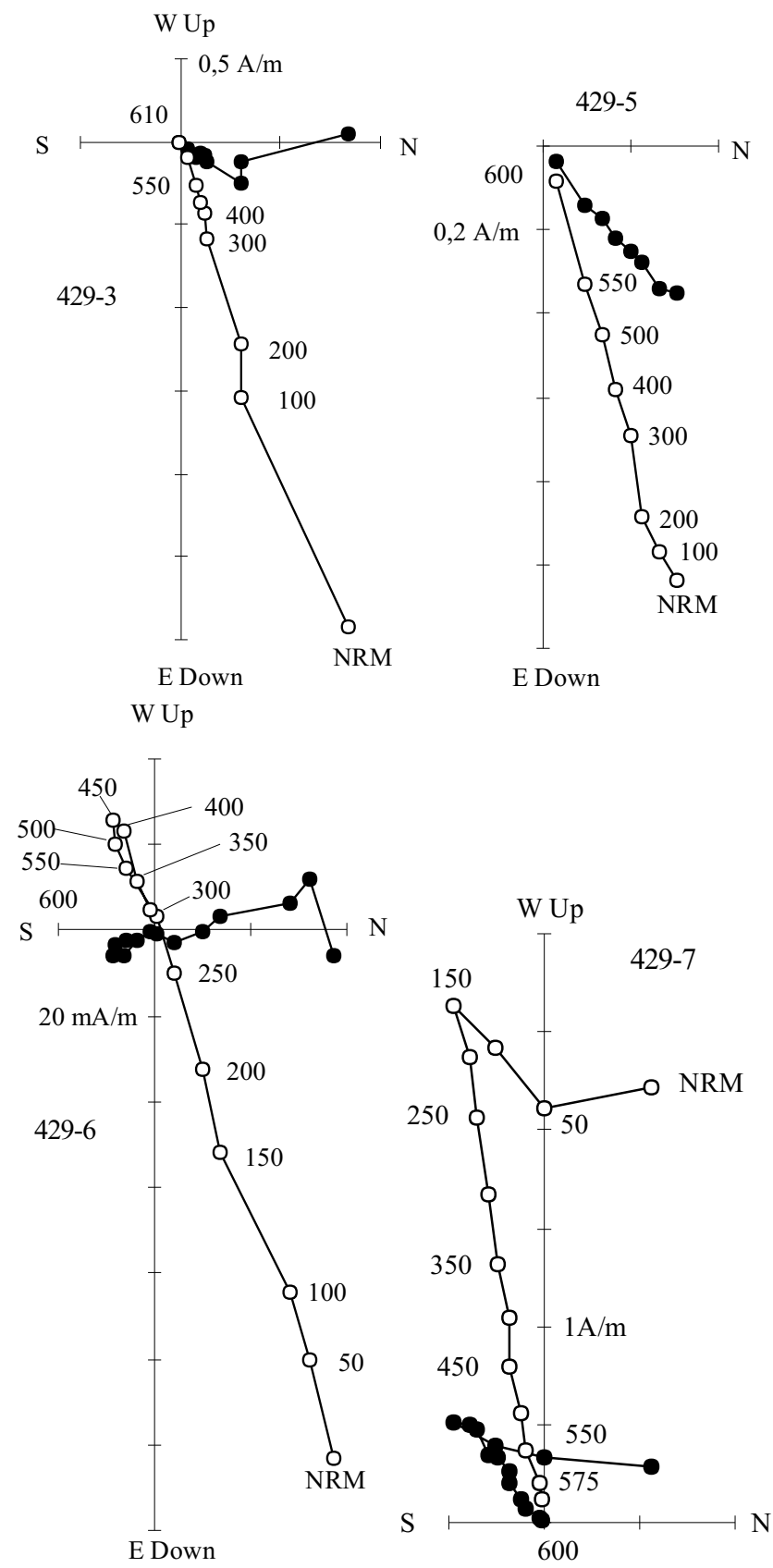

Fig. 4. Representative thermal demagnetization orthogonal plots for the contact zone for a basalt dike intruded into ignimbrites. Solid (open) symbols are projected onto the horizontal (vertical) plane. The plots are in stratigraphic coordinates. Temperatures are in ${ }^{\circ} \mathrm{C}$. Samples: 429-3 - basalt dike; 429-5 - contact zone (ignimbrite); 429-6 - ignimbrite, $1 \mathrm{~m}$ from dike; 429-7 - ignimbrite, $8 \mathrm{~m}$ from dike.

heating to $100-150^{\circ} \mathrm{C}$, resulting in a significant increase in kappa. The remaining TRM representing the Ergyvaam suite is of normal polarity. 


\subsubsection{Geochronology}

Three samples from the Ergyvaam suite show the most scatter in ages, perhaps due to either resetting by younger volcanism or due to mapping uncertainties. Sample 424-4A is located next to the Snezhninsk Caldera. A well-defined plateau age of $78.1 \pm 1.0 \mathrm{Ma}$ is significantly younger than the lower units of the Emuneret suite, but is consistent with the age and polarity from sample 464-1 from the upper part of this suite, and so it may reflect either resetting by younger volcanism or a mis-identified section. Sample 421-2 is located further from the caldera. It is also normal polarity but has an isochron age of $85.9 \pm 0.6 \mathrm{Ma}$, which is stratigraphically consistent with the younger and older units. The third site has two samples, 461-3 and 461-8. Sample 461-3 shows evidence of excess argon, while 461-8 shows a well defined plateau age of $89.8 \pm 2.1 \mathrm{Ma}$. This age is significantly older than the other samples from this unit, and is more consistent with ages from the underlying Chaun sequence. This sample is from a fault-bounded block, and it may be that this unit, identified as Ergyvaam is, in fact, older.

\subsection{The Koekvun' suite}

\subsubsection{Sampling localities}

Deposits of the Koekvun' suite, which are stratigraphically higher than the Voron'in suite, are represented by tuffaceous sandstones, tuffs, lavas, and ignimbrites of basic and intermediate composition. These deposits mark the end of the second basic to acid sequence of volcanic rocks (Drabkin, 1970a, b). Rocks of the Koekvun' suite in the Enmyvaam river basin are broken by fractures, and folded, perhaps related to the fact that they are located near the fault separating the inner and outer zones of the OCVB (Fig. 2). Basaltic dikes are often emplaced along the fractures. These dikes complicate the construction of a stratigraphic column, but are useful for paleomagnetic stability tests. Oriented samples were collected from three sections, locality 410 in the region of Lake El'gygytgyn and near the confluence of the right tributary of the Enmyvaam River, and along the Chanyvenvaam River (Fig. 2, localities 415, 416). It is not known whether each of the three sites sampled represent a sufficiently long time-average to remove secular variation

\subsubsection{Paleomagnetism}

The magnetic characteristics of the Koekvun' suite are quite variable (Table. 1), with ignimbrites from locality 410 having a ratio of magnetic intensity to magnetic susceptibility $(Q)$ of 3 while for tuffs at localities 415 and 416, it is less than or near 1 . Heating the tuffs to $400^{\circ} \mathrm{C}$ results in the destruction of $80-90 \%$ of magnetization, while the same temperature preserves up to $70 \%$ of the initial magnetization $\left(J_{\text {NRM }}\right)$ in ignimbrites. This difference can perhaps be attributed to the natural magnetization being a TRM in the ignimbrites and due to the physical alignment of the magnetic particles and partial TRM in the tuffs.

To check the magnetic stability of the characteristic thermal magnetization (TRM), a fold test was used at locality 416. At this locality the azimuths of the dip of paleohorizontal group around $45^{\circ}$ and $219^{\circ}$, and dips vary from $16^{\circ}$ to $29^{\circ}$, but because the units sampled could not be individually traced between sampling sites the modified fold test of McFadden (1990) was used. A comparison of the scatter of the site mean magnetic directions with respect to present horizontal (geographic) decreased significantly when corrected to paleo-horizontal (stratigraphic or tilt corrected) $N=3, \kappa s=26.4 ; \kappa g=19.0$. The characterisitic magnetization obtained from the ignimbrites and tuffs at the other sampling sites give steep $\left(>77^{\circ}\right)$ normal (positive) inclinations (see Fig. 4).

\subsubsection{Geochronology}

Two samples from the Koekvun' suite have ${ }^{40} \mathrm{Ar} /{ }^{39} \mathrm{Ar}$ ages younger than their stratigraphic age would suggest. Sample 410-3 from adjacent to Lake El'gygytgyn has a plateau age of $83.2 \mathrm{Ma}$, more consistent with those from upper units. It is possible that this site was mis-mapped and represents a younger sequence. Other samples from this site show resetting due to the $3.6 \mathrm{Ma}$ impact which formed Lake El'gygytgyn (Layer, 2000), and it is possible that this specimen was partially reset at that time. Sample 416-16, shows a highly disturbed age spectrum with excess argon. We interpret the age of this sample to reflect resetting by younger events in the Mechekrynnetveem basin.

\subsection{The Voron'in suite}

\subsubsection{Sampling localities}

In the vicinity of Lake El'gygytgyn, the ignimbrites of the Voron'in suite (Vor in Fig. 2) lie immediately above the ignimbrites of the Pykarvaam suite. However, in the region of the Ostantsov Mountains, the Pykarvaam suite is overlain by rocks of the Koekvun' suite, indicating that the Voron'in suite pinches out to the south of the lake. Around the lake, the rocks of the Voron'in suite are exposed in the eastern watershed section where they make up the summit of Mount Chuvyrinnet. They gradually pinch out to the south, giving way to deposits of the Koekvun suite (Fig. 2). This locality where one $8-\mathrm{m}$ section was sampled has to be considered as a "spot reading" of the geomagnetic field.

\subsubsection{Paleomagnetism}

Paleomagnetic samples were collected from a $9 \mathrm{~m}$ thick section represented by brown, strongly-welded ignimbrites. The rocks in this section, in contrast to the ignimbrites of the Pykarvaam suite, are strongly magnetized 
$\left(>3000 \times 10^{-3} \mathrm{~A} / \mathrm{m}\right.$; Table 1$)$ and have high magnetic susceptibilities $\left(>6500 \times 10^{-5}\right.$ SI units; Table 1). Demagnetization experiments indicate the magnetic carrier is magnetite, and that magnetization is a TRM because heating to $500^{\circ} \mathrm{C}$ results in the destruction of only $30 \%$ of the intensity of the initial or Natural Remanent Magnetization $\left(J_{\mathrm{NRM}}\right)$ without substantial changes in direction. In stratigraphic coordinates the characteristic magnetization, has a normal (positive) polarity with steep angles of inclination and shows a tight grouping within the sampled locality (Table 1). The similarity between these data and those obtained from the other localities indicates that it represents a primary residual magnetization of the rocks.

\subsubsection{Geochronology}

${ }^{40} \mathrm{Ar} /{ }^{39} \mathrm{Ar}$ analyses of four specimen cores from site 406 show consistent errorchron ages with a mean of $91.1 \pm 0.9 \mathrm{Ma}$. This age is consistent with, but slightly older than Chaun-series ages from other studies (e.g. Kelley et al., 1999; Ispolatov et al., 2004). Given the lack of well-defined isochrons, a combination of excess Argon and alteration is a possibility, especially considering that the locality is adjacent to the El'gygytgyn impact structure.

\subsection{The Pykarvaam suite}

\subsubsection{Sampling localities}

Deposits of the Pykarvaam suite (Pyk in Fig. 2) in the study area are gray to pink ignimbrites of moderately acidic to acidic composition representing the beginning of the second major cycle of volcanism (Drabkin, 1970a, b). The deposits are primarily from the external zone of the OCVB; the boundary with the inner zone more or less follows the valley of the Enmyvaam River near its upper reaches, and then just skirts the southeastern part of Lake El'gygytgyn (Fig. 2). The rocks of this suite are cut by numerous faults and fractures, making stratigraphic correlations between partial sections difficult, especially near the zone boundary where numerous dikes intrude the ignimbritic rock mass along its fractures. These ignimbrites can again be regarded as "spot readings" of the geomagnetic field.

\subsubsection{Paleomagnetism}

Oriented block samples were collected from shoreline outcrops on Lake El'gygytgyn (localities 401, 405, 407, 408), and along the main channel of the Enmyvaam River, near Mount Ostantsov (localities 418-420) (Fig. 2). At these localities isolated exposures of ignimbrite flows (from 3 to $21 \mathrm{~m}$ in thickness) were studied. Based on the marked difference in their magnetic susceptibilities and intensities of initial remanence, (Table 1) these units are different volcanic events, thus are separated in time. Their distribution through- out the section suggests that they represent sufficient time to average secular variation.

In the vicinity of Mount Ostantsov weakly-magnetized welded tuffs and ignimbrites (locality 420) are found alongside strongly-magnetized ones (locality 418), while the most strongly magnetized rocks exist on the northeastern part of Lake El'gygytgyn in the region of the Zvezda Massif (locality 405).

The magnetization is a thermoremanence, (TRM) with a small (5\% or less) amount of viscous magnetization. The thermal demagnetization curves indicate that the magnetic carrier in the ignimbrites is magnetite, with a Curie temperature of about $580^{\circ} \mathrm{C}$. Because the direction of this characteristic magnetization does not change during demagnetization, and since this direction is similar to that seen on the other localities sampled, it is assumed that it is a primary magnetization. Although the samples are from the flanks of the impact crater there is no sign of impact remagnetization. The samples used to determine the age of the impact were all "splash" from the moment of impact, and it is unlikely that the thermal event would penetrate into the subsurface.

In all the sections studied in the Pykarvaamsk suite, only normal (positive) polarities with steep $\left(>70^{\circ}\right)$ inclinations are found in stratigraphic coordinates, indicating a high paleolatitude (Table 1). The stratigraphic relationships between this and the overlying sequences are shown schematically in Fig. 5.

\subsubsection{Geochronology}

Two samples from the Pyrkarvaam suite from the vicinity of Lake El'gygytgyn were dated. Both show some evidence of possible resetting due to the impact, but both produce ages of $\sim 88.5 \mathrm{Ma}$, consistent with other Chaun Group ages (e.g. Kelley et al., 1999; Ispolatov et al., 2004) from Chukotka.

\section{Paleomagnetic analysis and pole positions}

To calculate the mean magnetic vectors and resulting Virtual Magnetic Poles (VGP) some data points were eliminated because they represented: dikes for which the age was unconstrained, gravels and other sediments that are poorer recorders than the basalts and ignimbrites, and localities where the dispersion parameter in stratigraphic coordinates $(\kappa s)$ was more than $10 \%$ smaller than the dispersion in geographic coordinates $(\kappa g)$. These samples are indicated by italic type in Table 1.

The mean vectors and VGPs are listed in Table 4 for the individual stratigraphic sections sampled, the whole selected sample set and the normal and reversed sub-sets. Figure 6 shows the selected vector directions of the characteristic magnetizations obtained from the data set. The data are shown in both geographic and stratigraphic reference frames, and with the reversed and normal polarities distinguished from one another. 


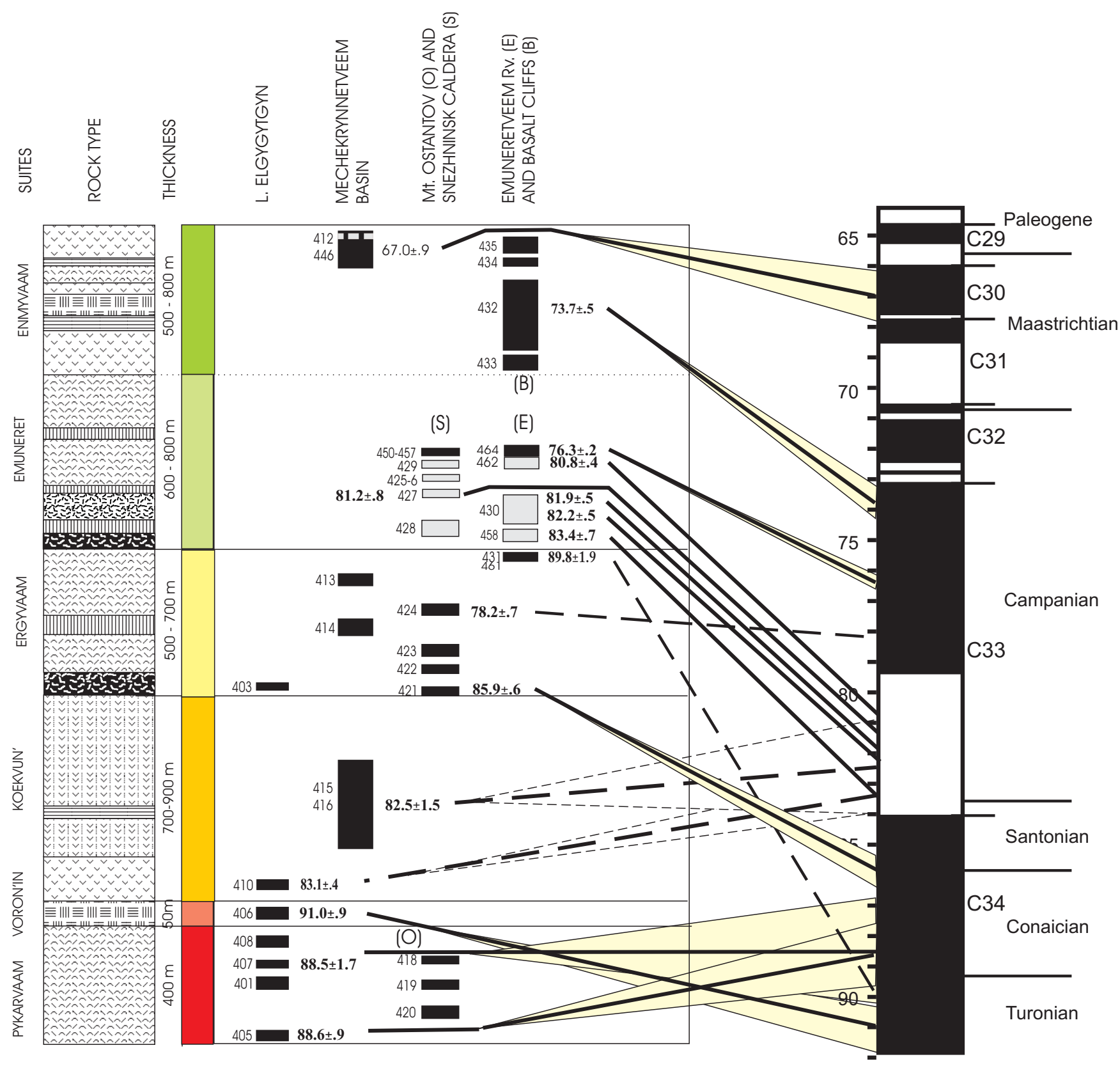

Fig. 5. Suites, Statigraphy and thickness are shown on the left with sampling locations separated out by region and approximate stratigraphic position. The numbered sampling sites with 40Ar/39Ar ages are connected to the reversal timescale from Gradstein et al. (2004). Ages from sites 461, 424 and 421 appear to be anomalous, as discussed in the text, and are connected by dashed lines. One sigma error bars are indicated by the yellow shading. Sites with reversed magnetization are shown in grey boxes with normal magnetization in black. The bars in site 412 indicate both polarities are present.

The tight mix of the selected magnetic directions from the various localities about the overall mean direction indicates that there is little or no change in the field direction over the roughly $22 \mathrm{Ma}$ represented by the samples. The mean VGPs for the individual localities are listed in Table 4 and displayed in Fig. 7, and again indicate no systematic changes in the pole positions with time. Figure 7 also shows the mean of the locality VGPs together with the mean VGP based on the mean of all the selected sample directions. This latter pole is considered a better representation of the mean VGP for the region because it is not biased by the variation in the number of samples taken at each locality. 


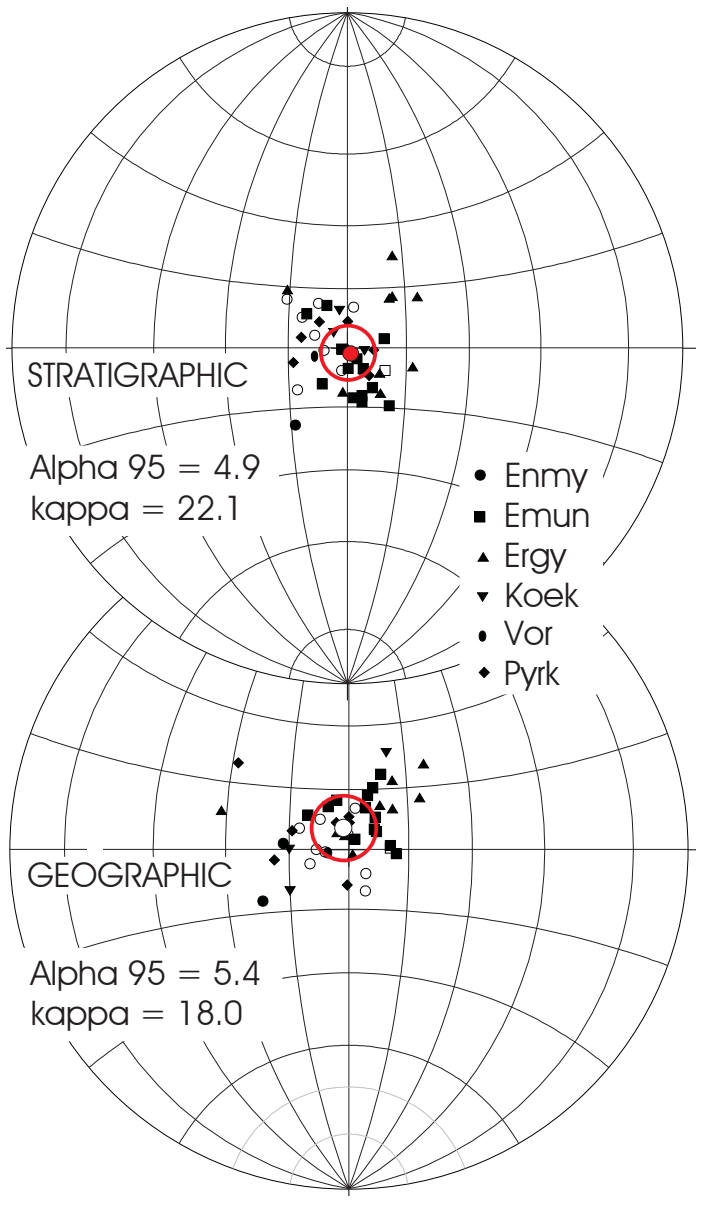

Fig. 6. Stereographic projections of the characteristic magnetic directions for each sample. Lower hemisphere plot, solid symbols are normal and open symbols reversed magnetizations inverted through the origin. $\alpha 95$ cones of confidence are indicated for each grouping (red circles).

The mean paleomagnetic pole for the selected data from the whole section is located at $171^{\circ} \mathrm{E}$ and $67^{\circ} \mathrm{N}$ (see Table 4). This pole position may be compared with the paleomagnetic poles for the same period of time from both the North American and eastern Siberian plates. The Paleomagnetic pole for the eastern Siberian platform for Cretaceous time has been determined in a number of indirect ways because there are few direct measurements. Besse and Courtillot (2002) extrapolated apparent polar wander paths for Eurasia and North America by reconstructing the positions of the major continental plates (primarily North America, South America, Africa and Europe) and combining their paleomagnetic pole positions. As little or no relative motion is expected between Eurasia and Siberia following the latest Paleozoic closure of the suture forming the Ural Mountains, the Eurasian APW path is used as a proxy for Siberia for Mesozoic time. In this way both polar wander paths were constructed using the same data set. It should be noted that

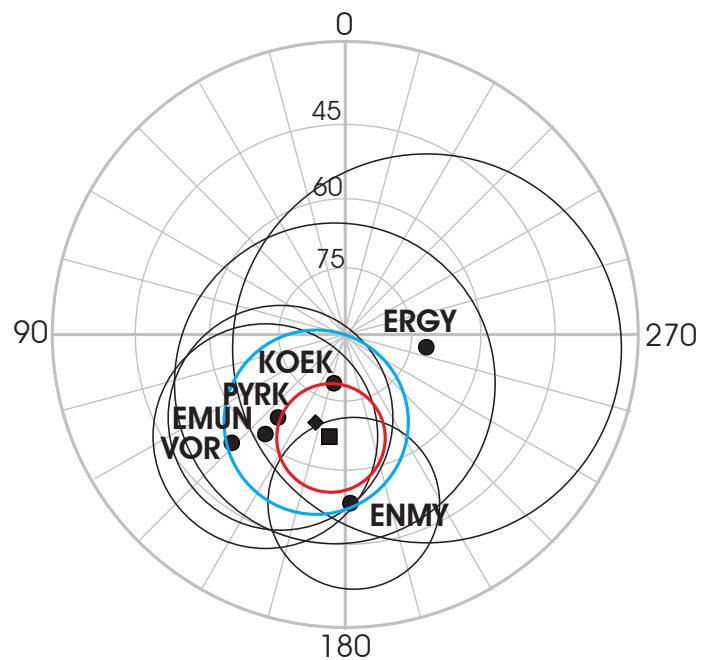

Fig. 7. A polar projection of the Virtual Geomagnetic Poles (VGPs) and their circles of $95 \%$ confidence $(\alpha 95)$ for the localities sampled, the mean of the locality means (black diamond with blue circle of confidence) and the VGP determined from the means of the individual samples (black square with red circle of confidence). Note that the latitude is truncated at $30^{\circ}$.

both the North American and Eurasian paleomagnetic poles show a still-stand in the Apparent Polar Wander Path (APW) with overlapping circles of confidence for the 70,80 , and $90 \mathrm{Ma}$ paleomagnetic poles, a time span that overlaps the whole El'gygytgyn section. This implies that any difference between the APW paths and the El'gygytgyn VGP must be due to relative motion.

When the pole position for the El'gygytgyn part of the Okhotsk-Chukotka volcanic belt is compared with the polar wander paths for the two continental blocks (Fig. 8) the face value interpretation is that the El'gygytgyn area, and by extrapolation a large part of the Okhotsk-Chukotka Volcanic belt, has moved southwest (in present day coordinates) with respect to the Eurasian and North American plates. The motion required to bring the VGPs for the El'gygytgyn area into conformity with the North American pole is considerably less than that required for the Eurasian pole. In terms of paleogeographic reconstructions, the eastern end of the OCVB appears more closely linked to the North American plate than Eurasia, and strengthens the ties between the South Anuyi and Southern Brooks Range sutures.

\section{Magnetostratigraphy}

The paleomagnetic data, in conjunction with the data on the geochronology and stratigraphy of six suites of volcanic and volcanogenic-sedimentary rock sequences in the Enmyvaam basin, has allowed the development of a preliminary magnetostratigraphic section for these Cretaceous rocks (Fig. 5). 


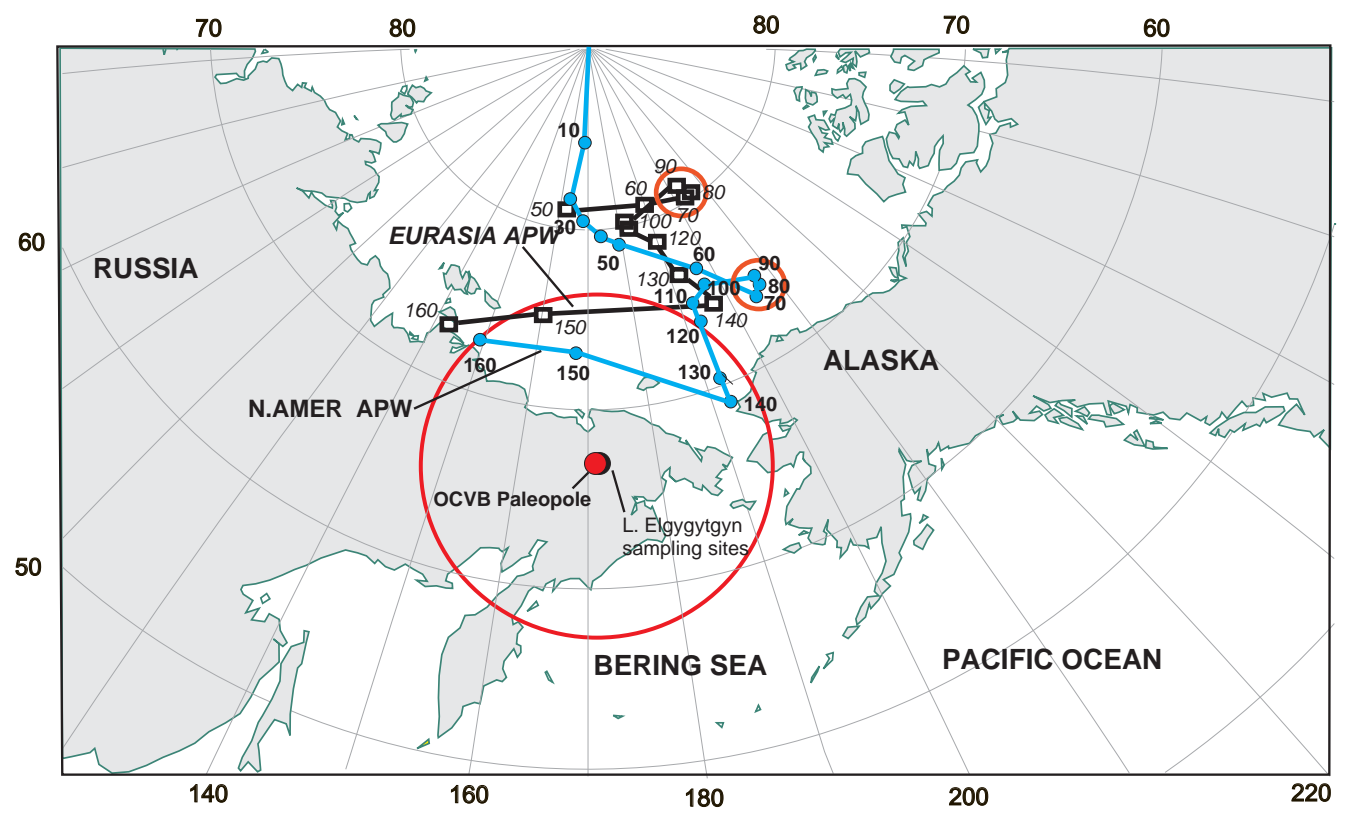

Fig. 8. Paleomagnetic pole (red dot) derived from localities near L. El'gygytgyn (partially covered black dot) is shown with its alpha 95 cone of confidence (red circle). For comparison, the relevant section of the Apparent Polar Wander paths for North America (blue dots and normal type) and Siberia (black squares and italic type) from Besse and Courtillot (2002) together with the $\alpha 95$ cone of confidence about the mean of the Paleomagnetic poles for 70,80 and $90 \mathrm{Ma}$ (red circles).

Table 4. Summary data for the El'gygytgyn region.

\begin{tabular}{llrlllllllll}
\hline & \multicolumn{10}{c}{ Means of stratigraphic units and means of means. } \\
suites & $D s$ & $I s$ & $N$ & $\kappa$ & $R$ & $\alpha 95$ & $d m$ & $d p$ & VGP lon & VGP lat \\
\hline Enmy & 158.2 & 82.7 & 14 & 35.95 & 13.64 & 7 & 13.1 & 12.8 & 181.7 & 53.2 \\
Emun & 263.8 & 83.0 & 9 & 24.17 & 8.67 & 10.7 & 20.9 & 20.4 & 141.2 & 61.8 \\
Ergy & 40.7 & 74.5 & 7 & 13.64 & 6.56 & 17 & 30.7 & 27.8 & 261.2 & 71.6 \\
Koek & 354.8 & 84.3 & 3 & 83.33 & 2.98 & 14 & 26.8 & 26.4 & 167.0 & 78.7 \\
Voro & 255 & 79.0 & $1\left(5^{*}\right)$ & $(527)^{*}$ & & & & & 133.8 & 55.6 \\
Pyrk & 278.2 & 83.9 & 6 & 41.43 & 5.88 & 10.5 & 20.7 & 20.3 & 141.0 & 66.2 \\
Mean of N & 76.1 & 88.5 & 30 & 22.0 & 28.7 & 5.7 & 11.4 & 11.4 & 179.7 & 68.1 \\
Mean of R & 73.6 & -84.7 & 10 & 23.0 & 9.6 & 10.3 & 20.3 & 20.1 & 150.3 & 62.2 \\
Mean of suites & 304 & 87.6 & 6 & 65.49 & 5.92 & 8.3 & 16.6 & 16.5 & 161.5 & 69.2 \\
Mean of samples & 238.3 & 89.8 & 40 & 22.15 & 38.24 & 4.9 & 9.8 & 9.8 & 171.0 & 67 \\
\hline
\end{tabular}

$D s, I s$, Declination and Inclination of the mean magnetic vector in stratigraphic (tilt corrected) coordinates; $N$ number of samples used in calculating the mean; $\kappa$ is the best estimate of kappa (Fisher, 1953); $R$ the normalized vector sum and $\alpha 95$ the cone of $95 \%$ confidence about the mean direction; $d m, d p$ are the axes of the cone of confidence about the resultant paleomagnetic poles. The means are shown for all selected normal $(\mathrm{N})$ and reversed $(\mathrm{R})$ magnetizations together with the means of suites and means of sample sites. Note that the Voron'in suite has a single site, the numbers with * indicate the number of individual samples from the single block sample.

The whole sequence can be divided into four zones of geomagnetic polarity. The lower zone of normal polarity includes deposits of the Pykarvaam, Voron'in, Koekvun' and Ergyvaam suites, which together make up the second sequence of mafic to felsic volcanism and the beginning of the third sequence. The lower normal polarity zone, which we now correlate with the Cretaceous Normal Superchron, is followed by a zone of reverse polarity, which is seen in deposits of the Emuneret suite sampled along the Enmyvaam river from the Snezhninsk Caldera down to the junction with the Emuneretveem River. Rocks of overlying the Enmyvaam suite are normally magnetized except for a single reversely magnetized basalt flow (and adjacent baked gravel) in the uppermost part of the section (locality 412, Fig. 1).

Our new ${ }^{40} \mathrm{Ar} /{ }^{39} \mathrm{Ar}$ ages are shown in Table 2. The quality of some of the age spectra are poor due to alteration or resetting. However, for samples taken stratigraphicaly below the reversed interval, all of which are normally magnetized, most 
of the ${ }^{40} \mathrm{Ar} /{ }^{39} \mathrm{Ar}$ ages group tightly between 88 and $91 \mathrm{Ma}$ indicating that the normal magnetization is indeed within the Cretaceous Normal Superchron. The exceptions are two samples from the Ergyvaam suite, one of which shows an anomalously young age, and the other which is old. The young sample was taken near the Snezhninsk caldera rim (locality 424) which gives an age of 78.1 $\pm 1.0 \mathrm{Ma}$. This age is similar to that of the reversed polarity samples of the caldera (e.g. locality $427 ; 81.2 \pm 0.2 \mathrm{Ma}$ ) and so may have been partially reset by the caldera forming event. The anomalous old age sample is from locality 461 , which gives one of the oldest ages seen in the whole section. The data for these samples (461-3, 461-8) show evidence of alteration which may have led to ages which are too old. It is also possible that the samples from the lowermost part of the section represent an older suite of rocks. Two normally magnetized samples from the Koekvun' suite in the Mechekrynnetveem basin (locality 416) and near Lake El'gygytgyn (locality 410) give ages which fall in the $\mathrm{C} 33$ reversed subchron, although the large error bars suggest that they could be in the Cretaceous normal superchron.

The overlying reversely magnetized units seen in both the region of the Snezhninsk caldera and near the mouth of the Emuneretveem river give several ${ }^{40} \mathrm{Ar} /{ }^{39} \mathrm{Ar}$ ages which place them clearly within reverse chron 33 (79.1-84 Ma) (Gradstein et al., 2004). Higher in the Emuneretveem river section, a normal polarity unit (464) gives an age of $76.3 \pm 0.2 \mathrm{Ma}$ which is consistent with the predicted polarity; thus this section may preserve a polarity transition.

The average K-Ar age of basalts in the Enmyvaam suite from zones of normal polarity was $77 \pm 5 \mathrm{Ma}$ with variations from 81 to $73 \mathrm{Ma}$ (10 measurements; Belyi, 1998). This age range encompasses the ${ }^{40} \mathrm{Ar} /{ }^{39} \mathrm{Ar}$ age from locality 432 which gives a good plateau age for the Basalt Cliffs of $73.7 \pm 0.5 \mathrm{Ma}$. The K-Ar age of the single reversely magnetized basalt from the top of the Enmyvaam suite in the Mechekrynnetveem basin was $70 \pm 10 \mathrm{Ma}$ (one analysis; Belyi and Belaya, 1998). This is in accord with the ${ }^{40} \mathrm{Ar} /{ }^{39} \mathrm{Ar}$ age of 67.0 $\pm 0.9 \mathrm{Ma}$ for the same unit (locality 412), although this age spectrum indicates some argon loss, and so might be a minimum age.

\section{Conclusions}

The locations in the Okhotsk-Chukotka volcanic belt that were sampled are thought to span the upper two thirds of the whole OCVB sequence. A combination of K-Ar and ${ }^{40} \mathrm{Ar} /{ }^{39} \mathrm{Ar}$ dating together with the pattern of magnetic reversals seen in the sections indicate that the age range is from about $90 \mathrm{Ma}$ to about $67 \mathrm{Ma}$. The magnetic vectors show very steep inclinations, and thus a Virtual Geomagnetic Pole located near to the site. Comparing this VGP with the Paleomagnetic Poles representing the same time span for both Eurasia (the proxy for Siberia) and North America shows that there has been southwesterly relative motion with respect to the Siberian platform and more limited southwesterly translation with respect to the North American plate. This is consistent with the current tectonic setting, inasmuch as the fold and thrust belts of Siberia indicate considerable crustal shortening (although much of this may be pre-Late Cretaceous) thus separating the Chukotka and Eurasian poles. The southerly component of the relative motion of the OCVB pole indicates that the El'gygytgyn section of the OCVB was north of its present geographic location prior to the collision between the terranes from the Pacific side with those comprising the Chukotka-Alaska composite terrane.

Acknowledgements. This work was supported by US National Science Foundation grants OPP90-24088, OPP92-24029, OPP9500241 and State of Alaska funds through the Geophysical Institute of the University of Alaska. We would also like to thank our many Russian collaborators, particularly Pavel Minyuk and B. V. Belyi for their political and intellectual support. The two reviewers, Peter Hauessler and Alexander Kuzmichev together with editor Elizabeth Miller greatly improved the original manuscript.

\section{References}

Akinin, V. V. and Khanchuk, A. I.: The Okhotsk-Chukotka Volcanogenic Belt: Age revision based on new ${ }^{40} \mathrm{Ar} /{ }^{39} \mathrm{Ar}$ and U-Pb isotope data, Dokl. Earth Sci., 405, 1131-1135, 2005.

Belyi, V. F.: Geology of Okhotsk-Chukchi volcanogenic belt, North East Interdisciplinary Research Institute Magadan, Russian Academy of Sciences Far East Branch, 76 pp., 1994 (in Russian).

Belyi, V. F.: Topical questions of phytostratigraphy of "Middle Cretaceous of North-East USSR, North East Interdisciplinary Research Institute, Magadan, Russian Academy of Sciences Far East Branch, 34 pp., 1988 (in Russian).

Belyi, V. F. and Belaya, B. V.: The Late Stage of the OkhotskChukchi Volcanic Belt development (the Emnyvaam River upper run area), North East Interdisciplinary Research Institute, Magadan, Russian Academy of Sciences Far East Branch, (in Russian) 107 pp., 1998.

Besse, J. and Courtillot, V.: Apparent and true polar wander and the geometry of the geomagnetic field over the last $200 \mathrm{Ma}$, J. Geophys. Res., 107(B11), 2300, doi:10.1029/2000JB000050, 2002.

Drabkin, I. E. (Ed.): Geology of USSR, North-East USSR, Geological structure, Nedra, Moscow, Book 1, Vol. 30, 548 pp., 1970a (in Russian).

Drabkin, I. E. (Ed.): Geology of USSR, North-East USSR, Geological structure, Nedra, Moscow, Book 2, Vol. 30, 536 pp., $1970 \mathrm{~b}$ (in Russian).

Filimonova, L. G.: Regularity of development of volcanicity and ore formation of active pacific margins, Nerda, Moscow, 159 pp., 1985 (in Russian).

Filippova, G. G.: About age of floristic complexes from Upper Mesozoic sediments of North-East USSR, in: Mesozoic of North-East USSR, Abstracts of stratigraphy conference, Magadan, 97-99, 1975 (in Russian). 
Filippova, G. G.: Cretaceous Floras from basin of middle run area of Anadyr river, in: Stratigraphy and Paleontology of Paleozoic and Mesozoic sediments of North-East USSR, Geological fund of RSFSR, Moscow, 154-157, 1984 (in Russian).

Fisher, R. A.: Dispersion on a sphere, Proc. R. Soc. Lon. Ser.-A, 217, 295-305, 1953

Hourigan, J. K. and Akinin, V. V.: Tectonic and chronostratigraphic implications of new ${ }^{40} \mathrm{Ar} /{ }^{39} \mathrm{Ar}$ geochronology and geochemistry of the Arman and Maltan-Ola volcanic fields, Okhotsk-Chukotka volcanic belt, northeastern Russia, Geol. Soc. Am. Bull., 116, 637-654, 2004.

Gradstein, F., Ogg, J., and Smith, A.: A Geologic Timescale 2004, Cambridge University Press, 589 pp., 2004.

Ispolatov, V. O., Tikhomirov, P. L., Heizler, M., and Cherepanova, I., Yu.: New ${ }^{40} \mathrm{Ar} /{ }^{39} \mathrm{Ar}$ ages of Cretaceous continental volcanics from central Chukotka: Implications for initiation and duration of volcanism within the northern part of the Okhotsk Chukotka Volcanic Belt (northeastern Eurasia), J. Geol., 112, 369-377, 2004.

Kelley, S. P., Spicer, R. A., and Herman, A. B.: New ${ }^{40} \mathrm{Ar} /{ }^{39} \mathrm{Ar}$ dates for the Cretaceous Chauna Group tephra, north-eastern Russia, and their implications for the geologic history and floral evolution of the North Pacific region, Cretaceous Res., 20, 97-106, 1999.

Khramov, A. N.: Paleomagnetology, Nedra, Leningrad, 312 pp., 1982 (in Russian).

Lanphere, M. A. and Dalrymple, G. B.: First-principles calibration of ${ }^{38} \mathrm{Ar}$ tracers: Implications for the ages of ${ }^{40} \mathrm{Ar} /{ }^{39} \mathrm{Ar}$ fluence monitors, US Geological Survey Professional Paper, 1621, 10 pp., 2000.

Layer, P. W.: Argon-40/Argon-39 age of the El'gygytgyn impact event, Chukotka, Russia, Meteorit. Planet. Sci., 35, 591-599, 2000.

Layer, P. W., Hall, C. M., and York, D.: The derivation of ${ }^{40} \mathrm{Ar} /{ }^{39} \mathrm{Ar}$ age spectra of single grains of hornblende and biotite by laser step heating, Geophys. Res. Lett., 14, 757-760, 1987.

Lebedev, E. L.: Stratigraphy and age of Okhotsk-Chukchi volcanic belt, Nauka, Moscow, 175 pp., 1987 (in Russian).

McDougall, I. and Harrison, T. M.: Geochronology and Thermochronology by the ${ }^{40} \mathrm{Ar} /{ }^{39} \mathrm{Ar}$ method, Oxford University Press, 2nd edn., 269 pp., 1999.

McFadden, P. L. and McElhinny, M. W.: Classification of the reversal test in paleomagnetism, Geophys. J. Int., 103, 725-729, 1990.

Newberry, R. J., Layer, P. W., Burleigh, R. E., and Solie, D. N.: New ${ }^{40} \mathrm{Ar} /{ }^{39} \mathrm{Ar}$ dates for intrusion and mineral prospects in the eastern Yukon-Tanana Terrane, Alaska-Regional patterns and significance, in: Geologic studies in Alaska, edited by: Gray, J. E. and Riehle, J. R., US Geological Survey, 1996, Professional Paper, 1595, 131-159, 1998.

Nokleberg, W. J., Parfenov, L. M., Monger, J. W. H., Baranov, B. V., Bundtzen, T. K., Byalobzhesky, S. G., Feeney, T. D., Fujita, K., Gordey, S. P., Grantz, A., Khanchuk, A. I., Natal'in, B. A., Natapov, L. M., Norton, I. O., Patton Jr., W. W., Plafker, G., Scholl, D. W., Sokolov, S. D., Sosunov, G. M., Stone, D. B., Tabor, R. W., Tsukanov, N. V., Vallier, T. L., and Wakita, K.: Summary Circum-North Pacific Tectonostratigraphic Terrane Map, USGS Open-File Report 96-727 and Canadian Geol. Survey Report 3428, scale 1:10000 000, 1996.

Parfenov, L. M.: Tectonics of the Verkhoyansk-Kolyma Mesozoides in the context of plate tectonics, Tectonophysics, 199, 319-342, 1991.

Raikevitch, M. N.: Magnetostratigraphic Studies of Cretaceous Volcanic Rocks, in: Magnetostratigraphic Studies of Phanerozoic Rocks, edited by: Linkova, T. I. and Izmailov, L. I., North East Interdisciplinary Research Institute, Magadan, Russian Academy of Sciences Far East Branch, 17-30, 1995 (in Russian).

Samson, S. D. and Alexander E. C.: Calibration of the interlaboratory ${ }^{40} \mathrm{Ar}-{ }^{39} \mathrm{Ar}$ dating standard, MMhb1, Chem. Geol., 66, 27-34, 1987.

Samylina, V. A.: Paleobotanical substantiation of stratigraphy of Jurassic, Lower Cretaceous and Senomanian sediments of NorthEast USSR, in: Abstracts of stratigraphy conference, Mesozoic of North-East USSR, Magadan, 131-132, 1975 (in Russian).

Schepetov, S. V.: Stratigraphy of Cretaceous continental sediments of Omsukchan region (Northern Okhotsk region), North East Interdisciplinary Research Institute, Magadan, Russian Academy of Sciences Far East Branch, 60 pp., 1988 (in Russian).

Schepetov, S. V.: Stratigraphy of Continental Cretaceous of SouthWestern flank of Kolyma highland, North East Interdisciplinary Research Institute, Magadan, Russian Academy of Sciences Far East Branch, 160 pp., 1991 (in Russian).

Steiger, R. H. and Jager, E.: Subcommission on geochronology: convention on the use of decay constants in geo- and cosmochronology, Earth Planet. Sc. Lett., 36, 359-362, 1977.

York, D., Hall, C. M., Yanase, Y., Hanes, J. A., and Kenyon, W. J.: ${ }^{40} \mathrm{Ar} /{ }^{39} \mathrm{Ar}$ dating of terrestrial minerals with a continuous laser, Geophys. Res. Lett., 8, 1136-1138, 1981.

Zonenshain, L. P., Kuzmin, M. I., and Natapov, L. M.: Geology of the USSR: A Plate-Tectonic Synthesis, edited by: Page, B. M., Amer. Geophys. Union, Geodynamic Series, 21, 242 pp., 1990. 